\title{
Cinsel Eğitime Yönelik Tutum Ölçeği: Güvenilirlik ve Geçerlilik Çalışması
}

\author{
Şehnaz CEYLAN* \\ İsmihan ARTAN ** \\ Fatma Betül KURNAZ ADIBATMAZ ${ }^{* * *}$
}

\begin{abstract}
Öz: Araştırmada Cinsel Eğitime Yönelik Tutum Ölçeği (CETÖ)'nin geliştirilmesi amaçlanmıştır. Denemelik formu ve Ebeveynler İçin Cinsel İletişim Ölçeği 199 kişiye uygulanmış, elde edilen veriler kullanılarak Açımlayıcı Faktör Analizi (AFA) yapılmıştır. Nihai form 39 maddedir ve dört faktörlüdür. Elde edilen veriler üzerinde Doğrulayıcı Faktör Analizi (DFA) uygulanmış ve uyum iyiliği indislerinin yüksek olması nedeniyle yapının doğrulandığı sonucuna ulaşılmıştır. Nihai form Toplumsal Cinsiyet Algısı Ölçeği ile birlikte üçüncü bir grupta (N=200) tekrar denenerek elde edilen veriler üzerinde DFA yapılarak sonuçlar kontrol edilmiştir. Ölçeğin, cinsel eğitime yönelik tutumları belirlemede geçerli sonuçlar üretebildiği sonucuna ulaşılmıştır. Ayrıca ebeveynlerin cinsiyetlerinin cinsel eğitime yönelik tutumlarında anlamlı bir farka yol açmadığı ancak öğrenim düzeylerinin cinsel eğitime yönelik tutumlarında yükseköğretim mezunlarının lehine anlamlı bir farka yol açtığı belirlenmiştir. Ebeveynlerin cinsel eğitime yönelik tutumları ile cinsel eğitimde kullandıkları iletişim dili arasında pozitif ve manidar ilişkilerin olduğu belirlenmiştir.
\end{abstract}

Anahtar Sözcükler: Cinsel Eğitim, Tutum, Cinsel Eğitime Yönelik Tutum

\section{Attitude Scale Towards Sexual Education: Reliability and Validity Study}

\begin{abstract}
In this study, it was aimed to develop the Attitude Scale towards Sexual Education (ASSE). A form and Communication Language Scale Used in Sexual Education were applied to 199 people for the purpose of experimentation and Confirmatory Factor Analysis (CFA) was performed using the obtained data. The final form is 39 items and has four factors. Confirmatory factor analysis was applied on the data obtained and it was concluded that the structure was confirmed due to the high index of goodness of fit. The final form was tried again in a third group with the "Gender Perception Scale" and the results were checked by confirmatory factor analysis on the obtained data. It was concluded that the scale can produce valid results in determining attitudes towards sexual education. In addition, the sex of the parents did not cause a difference in their attitudes towards sexual education; however, it was determined that their education level caused a difference in favor of higher education graduates in their attitudes towards sexual education. It has been determined that there are positive and significant relationships between parents' attitudes towards sexual education and the language of communication they use in sexual education.
\end{abstract}

Keywords: Sexual Education, Attitude, Attitude Towards Sexual Education

* Karabük Üniversitesi, Sağlık Bilimleri Fakültesi, Çocuk Gelişimi Bölümü, Karabük, Türkiye, e-posta: sehnazceylan@karabuk.edu.tr, ORCID: https://orcid.org/0000-0001-9313-7353

** Hacettepe Üniversitesi, Sağlık Bilimleri Fakültesi, Çocuk Gelişimi Bölümü, Ankara, Türkiye, e-posta: ismihan@hacettepe.edu.tr, ORCID: https://orcid.org/0000-0002-8868-7593

*** Karabük Üniversitesi, Edebiyat Fakültesi, Eğitim Bilimleri Bölümü, Karabük, Türkiye, e-posta: betulkurnaz@karabuk.edu.tr, ORCID: https://orcid.org/0000-0002-7042-2159 
Tüm insanların bütün yaşamları boyunca cinsel varlıklar olduğu; cinselliğin kişiliğin bir parçası olduğu; insan sağlığı, refahı ve mutluluğu için temel bir unsur olduğu kabul edilebilir. SIECUS'a (The Sexuality Information and Education Council of the United States) göre cinsellik, diğer bir kişiyle cinsel olarak yaşananlardan farklı bir şeydir. Cinsellik aynı zamanda insanın kendini algılayışı, bedenini algılayışı, bir kız çocuk/kadın veya erkek çocuk/erkek olarak kendini nasıl hissettiği, giyim tarzı, hareketleri, konuşması, başka kişilere karşı davranışları ve diğer kişiler hakkında nasıl hissettiğidir (akt: Bruess ve Greenberg, 2004, s. 4). Yaşamın önemli bir parçası olan cinsellik, insanın doğumundan başlayan ve yaşam boyu devam eden fizyolojik bir gereksinimdir (Erenoğlu ve Bayraktar, 2017; Kristiana, Jamaris ve Sumantri, 2006; Opara, Eke ve Akani, 2010). Yapılan çalışmalar, cinsel eğitimin doğumda başlayan yaşam boyu devam eden bir süreç olduğunu doğrulamıştır (Flanagan, 2011; Kurtuncu, Utas Akhan, Tanır ve Yıldız, 2015; Yuhong, 2004; Yonghong, 2007). Doğumla başlayan cinsellik; fiziksel, sosyal, kültürel ve psikolojik boyutlara sahiptir. Cinsel gelişim insan yaşamında kaçınılmazdır ve bir cinsel sağlık göstergesidir. Dünya Sağlık Örgütü (World Health Organization, 2006), cinsel sağlığı "cinsellik boyutuyla sadece halsizlik, işlev bozukluğu vb. olarak değil; fiziksel, duygusal, zihinsel ve sosyal olarak da iyi olma hali" olarak tanımlamaktadır. Cinsel sağlı̆̆ın korunması ve sürdürülmesi için tüm kişilerin cinsel haklarına saygı göstermek ve haklarını korunmak gerektiği savunulmaktadır. Bu nedenle bireyin cinselliğe verdiği önemle, cinsellik algısıyla ve tutumlarıyla ilişkilidir (Erenoğlu ve Bayraktar, 2017; Ganji, Emamian, Maasoumi, Keramat ve Khoei, 2017).

Cinsel tutumlar kendiliğinden oluşmamaktadır. Tutumlar insanın kendisi, çevresi ve genel olarak yaşam hakkında ne düşündüğüyle ilişkilidir. Tutumları, tutumların nasıl geliştirildiğini ve ölçüldüğünü daha iyi anlamak sağlık eğitimi çıtılarının temel taşlarındandır (McNab, 1976). İnsanların cinselliğe yönelik tutumlarını ve düşüncelerini kültür, medya, toplumsal değerler, din, bireylerin sosyo-ekonomik durumları, aile yapıları, ebeveynlerinin cinsel eğitim düzeyleri ve tutumları gibi faktörler etkilemektedir (Bayhan ve Artan, 2005; Pop ve Rusu, 2015). Cinsellik tutumları, özellikle ebeveynler ve çocukları arasındaki etkileşimleri anlamak için önemli bir faktördür (McNab, 1976).

Bireysel olarak erken yaşlarda edinilen cinsiyet görüşleri ve ilkeleri, gençlerin ve yetişkinlerin cinsiyet psikolojisinin temellerini oluşturur ve bireyin yaşamındaki bireysel davranışları üzerinde doğrudan ve önemli etkiler yaratır (Zhina ve Dingchu, 2013). Çocuklara ve ergenlere verilen cinsel eğitim, cinsel sağlık ve üreme sağlığı ve genel iyi olma hallerinde önemli bir rol oynar (Pop ve Rusu, 2015). Cinsel davranışlar yalnızca biyolojik faktörlerden etkilenmez, sosyalleşme yoluyla karmaşık hale gelir. Çocukların cinsel davranışları sosyalleşmelerinden güçlü bir şekilde etkilenir. Sosyalleşme, çocukların cinselliğe ilişkin temel inançları, tutumları, değerleri, kültürel sembolleri, kavramları ve anlamları edindiği bir süreçtir. Aile, çocukların hayatlarının ilk yıllarında çocukların sosyalleşmesinde etkili olan ilk ve en önemli faktör olarak kabul edilir. Cinsel eğitim sosyalleşmenin ana bileşenlerinden biri olarak, çocukların cinsel sağlığının artması için oldukça önemlidir (Ganji ve diğerleri, 2017). Cinsel eğitim aynı zamanda, çocukların kendilerini korumaları konusunda güçlendirilmesinde de rol oynamaktadır (Opara ve diğerleri, 2010).

Cinsel eğitimin temelleri (tutumlar, inançlar, davranışlar ve değerler) erken çocukluktan itibaren atılır ve aile katılımıyla gerçekleşir. Eğitim çalışmalarının derinleşmesiyle; cinsel eğitimin cinsel fizyoloji, cinsel psikoloji ve cinsel ahlaki eğitimi kapsaması gerektiği, aynı zamanda okul öncesi çocuklar için cinsel eğitimin de olması gerektiği ortaya konmuştur (Pop ve Rusu, 2015; Zhina ve Dingchu, 2013). Purba (2012) cinsel eğitimin; çocukların kendi bedenlerine, çevrelerine ve karşı cinse ilişkin algılarını şekillendirdiğini ve bir kişi veya eğitimci tarafından çocukların cinsel haklarını nasıl kullandıklarına ilişkin çocuk cinselliği konusunda kullanılan eğitsel bir yöntem olduğunu vurgulamıştır. Bu nedenle, çocukların bedenlerini ve cinsiyetlerini doğru anlasınlar diye doğru rehbere ve yönlendirmeye gereksinimleri vardır. Ebeveynler çocukların ilk eğiticileridir. Ebeveynler çocuklarına cinsellikle ilgi doğrudan bilgi veren bir kaynaktır. Çocukların cinselliğe ilişkin tutumlarının ve değer yargılarının gelişmesinde oldukça önemlidir. Çocuklara cinselliğe ilişkin bilgileri, tutumları ve değer yargıları, ebeveynlerin çocuklarıyla konuşmaları, duygularını paylaşmaları, kıyafetlerini giydirmeleri ve vücutlarını tanıtmaları vb. davranışlarla gelişir (Eroğlu ve Gölbaşı, 2005).

Aile ve eğitimcilerin cinsel eğitime yönelik tutumlarını belirlemek amacıyla Türkiye' de ve farklı ülkelerde çalışmalar yürütülmüştür. Opara ve diğerleri (2010) annelerin cinsel eğitime yönelik algısıyla ilgili yaptıkları 
araştırmada annelerin büyük bir kısmının çocuklarının cinsel eğitime ihtiyaç duyduğunu ve çocukları eğitmenin hem anne hem de babanın sorumluluğu olduğu vurguladıklarını belirtmişlerdir. Ni (2003), tarafından 150 ebeveyn ve 160 öğretmenle yapılan çalışmada, ebeveynlerin ve öğretmenlerin, çocuklar için cinsel eğitimin öneminin farkında olduğu; bazı yeterliliklere sahip olmalarına rağmen, neredeyse hiçbir ebeveyn ve öğretmenin çocuklara yönelik resmi ve amaçlanan cinsel eğitimi uygulamadığını vurgulamıştır. Oktavianingsih ve Ayriza (2018), öğretmenlerin cinsel eğitimiyle ilgili bilgi ve inançlarını belirlemek amacıyla yaptıkları çalışma sonucunda; öğretmenlerin çocuklara cinsellik eğitimi öğretiminde sınırlı bilgiye sahip olduğunu bulmuşlardır. Tuğut ve Gölbaşı (2019), okul öncesi dönem çocuğu olan ebeveynlerin cinsel eğitim tutumlarının belirlenmesiyle ilgili yaptıkları araştırma sonucunda 3-6 yaş çocukların çoğunluğunun ebeveynlerine cinsellikle ilgili soru sorduğunu, ebeveynlerin çoğunun cinsel eğitimi desteklediğini, anne ve babaların çocuk cinsel eğitimine yönelik tutumlarının benzer olduğunu ve bu konuda cinsel eğitim alan ebeveyn sayısının yetersiz olduğunu saptamışlardır. İşler ve Gürşimşek (2018)'in cinsel eğitiminin gerekliliğiyle ilgili ebeveyn görüşlerini inceledikleri araştırmada ebeveynlerin çocukların doğru bilgilenmesi ve istismardan korunmaları için cinsel eğitimi gerekli gördüklerini, fakat çocuklarıyla cinsel konularda yeterince konuşma yapmadıklarını, konuşma yapan ebeveynlerin genel olarak kendilerini huzursuz ve yetersiz hissettiklerini belirtmişlerdir. Yapılan çalışmalar incelendiğinde ebeveynlerin cinsel eğitime yönelik olumlu tutum sergiledikleri, ancak bu konuda bilgi sahibi olmadıkları dikkat çekmektedir.

Cinsel eğitim programlarıyla çocuklar, beden farkındalığını, başkalarına ya da cinsel organlara dokunma/bakma kısıtlamaları içeren kuralları, mevcut koşullara uygun duyguların ve ifadelerin farkındalığını, kendine güvenme gibi temel içerikleri edinmelidir (Oktavianingsih ve Ayriza, 2018). Ülkemizde okullarda erken çocukluk döneminde henüz cinsel eğitim üzerine bir eğitim verilmediği görülmektedir. Ailede verilen cinsel eğitim, çocukların gelişimi açısından oldukça önemlidir. Birçok ülkede olduğu gibi ülkemizde de cinsellik konuları aile içinde rahatlıkla konuşulmamaktadır. Yetişkinlerin birçoğu çocukları cinselliğe ilişkin sorularına cevap vermenin ve çocuklarına cinsellikle ilgili bilgi vermenin oldukça zor olduğunu belirtmektedir. Bununla birlikte, çocukların cinsellikle çok fazla ilgili olmaması gerektiğine ilişkin yaygın bir düşünce de vardır (Flanagan, 2011). Dünya Sağlık Örgütü çocukların, cinsellikle ilgili bilgileri arkadaş çevresi ve medya gibi kaynaklardan öğrendiğini belirtmektedir. Hayatın önemli bir parçası olan cinselliğin eksik veya yanlış bilgi veren kaynaklardan öğrenilmesi, çocuğun cinsellik algısını olumsuz geliştirebilmektedir. Ailenin çocuklarına cinsel eğitim vermedeki tutumlarının çocukların cinsellik algılarını etkilediğini söylemek mümkündür (Eliküçük ve Sönmez, 2011; Eroğlu ve Gölbaşı, 2005; Tuğut ve Gölbaş1, 2019). Türkiye' de alanyazın incelendiğinde, ebeveynlerin cinsel eğitime yönelik tutumlarını belirlemek amaçlı kullanılabilecek bir ölçme aracının olmadığı görülmektedir. Bu çalışmanın amacı, anne babaların cinsel eğitimle ilgili tutumlarını belirlemeye yönelik bir ölçme aracı geliştirmek, bu ölçme aracının güvenilirliğini ve geçerliliğini kontrol etmek ve ilgili değişkenlerle bu ölçme aracından elde edilen sonuçlar arasındaki ilişkileri incelemektir. Araştırma soruları aşağıda verilmiştir.

1. Cinsel Eğitime Yönelik Tutum Ölçeği güvenilir ve geçerli sonuçlar üretmekte mi?

2. Anne ve babaların Cinsel Eğitime Yönelik Tutum Ölçeği'nden aldıkları puanlar arasında istatistiksel olarak fark var mi?

3. Öğrenim düzeyi farklı ebeveynlerin Cinsel Eğitime Yönelik Tutum Ölçeği'nden aldıkları puanlar arasında istatistiksel olarak fark var mı?

4. Cinsel Eğitime Yönelik Tutum Ölçeği ile Ebeveynler İçin Cinsel İletişim Ölçeği'nden elde edilen puanlar arasında ilişki var mı?

5. Cinsel Eğitime Yönelik Tutum Ölçeği ile Toplumsal Cinsiyet Algısı Ölçeği'nden elde edilen puanlar arasında ilişki var mı?

\section{Yöntem}

Araştırmanın bu bölümünde araştırmanın çalışma grubu, veri toplama aracının geliştirilmesi, verilerin toplanması ve çözümlenmesine ilişkin konularda bilgi verilmiştir. 


\section{Çalışma Grubu}

Araştırmada üç farklı çalışma grubundan veri toplanmıştır. Aşağıda bu çalışma gruplarıyla ilgili bilgiler verilmiştir.

Birinci Çalışma Grubu. Araştırmada ilk uygulamanın yapıldığı gruptan elde edilen veriler örtük değişkenin (cinsel eğitime yönelik tutum) nasıl bir yapı gösterdiğini ve bu özelliğe ilişkin davranış göstergelerinin ne olduğunu anlamaya yönelik olarak kullanılmıştır. Ön uygulamada üretilen maddeler denenmiş, hangi maddelerin ölçülen özellikle uyumlu olduğu ve hangilerinin uyumlu olmadığı incelenmiştir. $\mathrm{Bu}$ aşamada elde edilen istatistikler denemelik formun geliştirilmesine yönelik olarak kullanılmıştır. Yanıtlayıcılardan maddeleri okuduklarından ne düşündüklerine ilişkin bilgiler toplanmıştır. Birinci çalışma grubunu 50 anne ve 50 baba olmak üzere toplam 100 kişi oluşturmuştur. Ebeveynlerin özelliklerine ilişkin sayı ve yüzde değerleri Tablo 1'de verilmiştir.

Tablo I

Birinci Çalışma Grubuna İlişkin Özelliklerin Sayı ve Yüzde Değerleri

\begin{tabular}{|c|c|c|c|c|c|}
\hline \multirow{2}{*}{ Değişken } & & \multicolumn{2}{|c|}{ Anne } & \multicolumn{2}{|c|}{ Baba } \\
\hline & & Say1 & $\%$ & Sayı & $\%$ \\
\hline \multirow{3}{*}{ Yaş } & $20-39$ & 26 & 52 & 21 & 42 \\
\hline & 40 ve üzeri & 24 & 48 & 29 & 58 \\
\hline & Toplam & 50 & 100 & 50 & 100 \\
\hline \multirow{5}{*}{ Öğrenim durumu } & İlkokul mezunu & 12 & 24 & 8 & 16 \\
\hline & Ortaokul mezunu & 6 & 12 & 16 & 32 \\
\hline & Lise mezunu & 14 & 28 & 20 & 40 \\
\hline & Yükseköğretim mezunu & 18 & 36 & 6 & 12 \\
\hline & Toplam & 50 & 100 & 50 & 100 \\
\hline \multirow{4}{*}{ Çocuk sayısı } & Tek çocuk & 17 & 34 & 13 & 26 \\
\hline & İki çocuk & 19 & 38 & 26 & 52 \\
\hline & Üç ve daha fazla çocuk sahibi & 14 & 28 & 11 & 22 \\
\hline & Toplam & 50 & 100 & 50 & 100 \\
\hline
\end{tabular}

Tablo 1 incelendiğinde forma yanıt veren annelerin \%52'sinin 20-39 yaş aralı̆̆ında, \%36'sının yüksek öğretim mezunu, \%38'inin iki çocuklu olduğu; babaların \%58'inin 40 ve üzeri yaş aralığında, \%40'ının lise mezunu ve $\% 52$ 'sinin iki çocuklu olduğu görülmektedir. Ebeveynlerin yaş ortalaması $35,3 \pm 8$ olarak hesaplanmıştır.

İkinci Çalışma Grubu. Birinci çalışma grubundan ve uzman görüşlerinden yola çıkarak geliştirilen denemelik formu ile Ebeveynler İçin Cinsel İletişim Ölçeği birlikte uygulanmıştır. Ortak çocuğa sahip olan anne ve babaların cinsel eğitime yönelik tutumlarının benzer olabileceği görüşünden yola çıkılarak aynı evde yaşayan yalnız bir ebeveyn ölçme aracını doldurmuştur. Elde edilen veriler ölçülen özelliğin yapısını anlamaya yönelik olarak kullanılmış ve bu gruptan elde edilen veriler üzerinde Açımlayıcı Faktör Analizi (AFA) yapılmıştır. Geliştirilen denemelik formu Karabük ilinde yaşayan farklı öğrenim düzeyindeki 208 anne ve babaya uygulanmış, formlar incelenmiş, gelişigüzel doldurulan ya da önemli ölçüde eksik doldurulan formlar analiz dışında tutulmuştur. Bu aşamada analizler toplam 199 veriyle gerçekleştirilmiştir. İkinci çalışma grubunun özelliklerine ilişkin sayı ve yüzde değerleri Tablo 2' de verilmiştir.

Tablo II

Denemelik Formunun Uygulandı̆̆ı Çalışma Grubuna Illişkin Özelliklerin Sayı ve Yüzde Değerleri

\begin{tabular}{|c|c|c|c|c|c|}
\hline \multirow{2}{*}{ Değişken } & & \multicolumn{2}{|c|}{ Anne } & \multicolumn{2}{|c|}{ Baba } \\
\hline & & Say1 & $\%$ & Sayı & $\%$ \\
\hline \multirow{3}{*}{ Yaş } & $20-39$ & 81 & 68.0 & 50 & 62.5 \\
\hline & 40 ve üzeri & 38 & 32.0 & 30 & 37.5 \\
\hline & Toplam & 119 & 100 & 80 & 100 \\
\hline \multirow{5}{*}{ Öğrenim durumu } & İlkokul mezunu & 27 & 22.7 & 5 & 6.25 \\
\hline & Ortaokul mezunu & 14 & 11.7 & 7 & 8.75 \\
\hline & Lise mezunu & 32 & 26.9 & 24 & 30.0 \\
\hline & Yükseköğretim mezunu & 46 & 38.7 & 44 & 55.0 \\
\hline & Toplam & 119 & 100 & 80 & 100 \\
\hline Çocuk sayısı & Tek çocuk & 17 & 14.2 & 13 & 16.3 \\
\hline
\end{tabular}




$\begin{array}{lcccc}\text { İki çocuk } & 61 & 51.2 & 42 & 52.5 \\ \text { Üç ve daha fazla çocuk sahibi } & 41 & 34.6 & 25 & 31.2 \\ \text { Toplam } & 119 & 100 & 80 & 100\end{array}$

Tablo 2 incelendiğinde, forma yanıt veren annelerin \%68'inin 20-39 yaş aralığında, \%38.7'sinin yüksek öğretim mezunu, \%51.2'sinin iki çocuklu olduğu; babaların \%62.5'inin 20-39 yaş aralığında, \%55'inin yüksek öğretim mezunu ve \%52.5'inin iki çocuklu olduğu görülmektedir. Ebeveynlerin yaş ortalaması $33.3 \pm 6$ olarak hesaplanmıştır.

Üçüncü Çalışma Grubu. Üçüncü çalışma grubuna ikinci uygulamanın sonunda oluşturulan nihai form ile Toplumsal Cinsiyet Algısı Ölçeği (Altınova ve Duyan, 2013) birlikte uygulanmıştır. Bu grupta anne ve babaların sayısının eşit tutulması amaçlanmıştır. Ortak çocuğa sahip olan anne ve babaların cinsel eğitime yönelik tutumlarının benzer olabileceği görüşünden yola çıkılarak aynı evde yaşayan yalnız bir ebeveyn ölçme aracını doldurmuştur. Bu yolla elde edilen verilerin daha genellenebilir ve daha heterojen olması amaçlanmıştır. Veriler 100 anne ve 100 babadan toplanmıştır. Ebeveynlerin \%20'si ilkokul (n=40), \%20'si ortaokul $(\mathrm{n}=40), \% 40^{\prime} 1$ lise $(\mathrm{n}=80), \% 20^{\prime}$ si yüksek öğretim $(\mathrm{n}=40)$ mezunudur. Ebeveynlerin $\% 27^{\prime}$ sinin tek çocuğu (n=54), \%73'ünün iki ve daha fazla çocuğu $(n=146)$ vardır. Ebeveynlerin yaş ortalaması $34,2 \pm 7$ olarak hesaplanmıştır.

\section{Veri Toplama Araçları}

Araştırmada Cinsel Eğitime Yönelik Tutum Ölçeği (Ek 1) geliştirilmiş, bu ölçeğin geliştirilmesine ilişkin bulgular aşağıda açıklanmıştır. Ayrıca araştırmada geliştirilen bu ölçekle birlikte Ebeveynler İçin Cinsel İletişim Ölçeği ve Toplumsal Cinsiyet Algısı Ölçeği araştırma grubuna uygulanmıştır. Aşağıda ilgili ölçme araçlarına ilişkin bilgiler verilmiştir.

Cinsel Eğitime Yönelik Tutum Ölçeği'nin Geliştirilmesi. Veri toplama aracının geliştirilmesiyle ilgili aşamalar aşağıda sırasıyla anlatılmıştır:

- Türkiye'de anne ve babaların cinsel eğitim konusundaki eğilimleri ve görüşlerine ilişkin geniş bir alanyazın taraması (Ceylan ve Çetin, 2015; Eliküçük ve Sönmez, 2011; Erbil, Orak ve Bektaş, 2010; Göçgeldi, Tüzün, Türker ve Şimşek, 2007; İşler ve Gürşimşek, 2018; Sezgin ve Akyüz, 2018; Tuğrul ve Artan, 2001; Tuğut ve Gölbaşı, 2019; Tuzcuoğlu ve Tuzcuoğlu, 1996) yapılmıştır. Alanyazın taraması sonucunda anne ve babaların cinsel eğitimle ilgili eğilimleri incelenmiştir. Anne ve babaların cinsel eğitime yönelik görüşlerini içeren çalışmaların yanı sıra cinsel eğitimle ilgili kuramsal alan yazın (Artan ve diğerleri, 2015; Çalışır, 2011; Tuzcuoğlu ve Tuzcuoğlu, 2004; Yılmaz, 2017) taraması yapılmıştır. Elde edilen bilgiler doğrultusunda denemelik maddeler hazırlanarak küçük bir çalışma grubunda $(\mathrm{N}=100)$ denenmiştir. Bu aşamada ebeveynlerden maddeleri okuduklarında ne anladıklarına ilişkin veriler toplanmıştır.

- Denenen maddelerin anlaşılırlığı, anne ve babaların maddelerle ilgili görüşleri incelenerek deneme formunda yeniden düzenlenmiştir. Yeniden düzenlenen denemelik formda tüm kapsamı ölçebilecek geniş bir madde havuzu oluşturulmuştur $(\mathrm{k}=55)$. Madde havuzu oluşturulurken ölçülen özelliğin yapısını iyi yansıtabilmek amacıyla bilişsel, davranışsal ve duyuşsal boyutlardan çok sayıda madde yazılması amaçlanmıştır. Bilişsel boyutta 21, duyuşsal boyutta 21, davranışsal boyutta 12 madde yazılmıştır.

- Oluşturulan son form psikoloji alanında iki, çocuk gelişimi alanında iki, ölçme ve değerlendirme alanında iki olmak üzere altı uzmana gönderilmiştir. Uzmanlardan maddelerin ölçülen özelliğe uygunluğu, anlaşılırlığı, tek bir davranışı yoklayıp yoklayamaması vb. özellikler bakımından görüşlerini bildirmeleri istenmiş ve uzman görüşleri doğrultusunda maddeler yeniden gözden geçirilmiş̧tir. Nihai formda uzman görüşleri doğrultusunda bazı maddelerin anlatımında değişikliklere gidilmiş, madde sayısı aynı kalmıştır.

- Son hali verilen denemelik formun ölçtüğü psikolojik yapı iki farklı çalışma grubundan elde edilen verilerle incelenmiş ve elde edilen istatistikler değerlendirilmiştir.

Ebeveynler İçin Cinsel İletişim Ölçeği. Artan, Ceylan ve Adıbatmaz Kurnaz (2020) tarafından geliştirilen ölçme aracı, dört faktörlü 23 maddeden oluşmaktadır. Ölçekten elde edilen yüksek puanlar iletişim dilinin 
eğitsel açıdan uygun olduğu anlamına gelmektedir. Ölçeğin geliştirilmesi aşamasında üç farklı örneklem gruptan veri toplanmıştır. Birinci çalışma grubundan elde edilen verilerle ölçeğin yapısı açıklanmaya çalışılmış, ikinci çalışma grubundan elde edilen verilerle AFA yapılmış ve üçüncü çalışma grubundan elde edilen verilerle Doğrulayıcı Faktör Analizi (DFA) yapılarak sonuçlar kontrol edilmiştir. DFA sonucunda ölçeğin geçerli sonuçlar üretebileceğine ilişkin kanıtlar sunulmuştur. Ölçme aracının alt faktörlerinin iç tutarlılık katsayısının iki farklı örneklemde 0,70 ve 0,80 arasında değiştiği belirtilmiştir.

Toplumsal Cinsiyet Algısı Ölçeği. Altınova ve Duyan (2013) tarafından geliştirilen ölçek beşli Likert tipinde 25 maddeden oluşmaktadır. Ölçeğin geçerlilik ve güvenilirlik çalışması 443 yetişkinden elde edilen verilerle kontrol edilmiştir. Ölçekten 25 ile 125 aralığında puanlar elde edilmektedir. İlgili çalışmada ölçeğin iç tutarlılık katsayısının 0,87 olduğu bildirilmiştir. Ölçekte toplumsal cinsiyet eşitliği konusunda 15 olumsuz anlam taşıyan madde ve 10 olumlu anlam taşıyan madde vardır. Olumsuz anlam taşıyan maddeler ters puanlanmaktadır. Elde edilen toplam puanların yüksek olması bireyin eşitlikçi bir toplumsal cinsiyet algısına sahip olduğunu göstermektedir. Bu araştırmada bu ölçekle toplanan verilerin güvenilirliği 0,90 olarak hesaplanmıştır. Güvenilirlik katsayısının yüksek olması ve ölçtüğü özelliğin bu araştırmada geliştirilen ölçekle ilişkili olması nedeniyle bu ölçekle elde edilen verilerin ölçüt olarak kullanılmasının uygun olduğuna karar verilmiştir.

\section{Verilerin Toplanması}

Veri toplama araçlarının denemelik formlarının hazırlanmasının ardından etik kurul onayı alındı. Veriler Şubat-Temmuz 2019 tarihlerinde, 15 yaşından daha küçük en az bir çocuğu olan araştırmaya katılmaya gönüllü anne ve babalardan toplandı. Verilerin toplanması aşamasında ikinci çalışma grubuna CETÖ'nin denemelik formuyla birlikte Ebeveynler İçin Cinsel İletişim Ölçeği; üçüncü çalışma grubuna ise nihai formla birlikte Toplumsal Cinsiyet Algısı Ölçeği uygulanmıştır. Bu ölçeklerden elde edilen verilerin ölçüte dayalı geçerliğe ilişkin bulgular sunacağı düşünülmüştür.

\section{Verilerin Çözümlenmesi}

Verilerin çözümlenmesinde aşağıdaki işlemler gerçekleştirilmiştir.

- Kaiser-Mayer-Olkin (KMO) ve Barlett'in Sphericity değerleri incelenerek verilerin faktör analizine uygun olup olmadığı değerlendirilmiştir. KMO değerinin 0,70 ve 0,80 arasında ise orta, 0,80 ve 0,90 arasında ise iyi olduğu yorumu yapılabilir (Tavşancıl, 2005).

- Denemelik formun ikinci çalışma grubuna uygulanmasından elde edilen veriler üzerinde AFA uygulanmıştır. AFA, ölçek geliştirme çalışmalarında değişken azaltma ve faktörleri isimlendirmede kullanılmasının yanı sıra ortaya çıkan faktörlerin incelenmesiyle ölçülen örtük özelliğin anlaşılmasını kolaylaştırır (Çokluk, Şekercioğlu ve Büyüköztürk, 2010).

- AFA sonucuyla, ölçülen özelliğin çok bileşenli dört faktörlü bir yapı gösterdiğine karar verilmiştir. Bu bulgu, hem ikinci çalışma grubundan elde edilen verilerde hem de üçüncü çalışma grubundan elde edilen verilerde DFA uygulanarak doğrulanmıştır. DFA, kuramsal bir yapı çerçevesinde geliştirilen ölçme aracıyla yapının doğrulanıp doğrulanmadığını kontrol etmede kullanılır (Çokluk, Şekercioğlu ve Büyüköztürk, 2010).

- Faktör analizinde örneklem büyüklükleriyle ilgili farklı görüşler söz konusudur. Bu araştırmada ikinci çalışma grubunu 199, üçüncü çalışma grubunu 200 kişi oluşturmaktadır. Comrey ve Lee (1992), faktör analizinde 200 kişiden toplanan verilerin orta, 300 kişiden toplanan verilerin iyi sonuçlar verebileceğini; Tabachnick ve Fidell (2001), 150 kişiden elde edilen verilerle de yüksek faktör yük değerleri elde edilebileceğini; Kline (1994) 200 kişilik bir örneklemin genellikle yeterli olabileceğini belirtmektedir. Bu görüşler doğrultusunda bu çalışmada örneklem büyüklüğünün yeterli olduğu sonucuna ulaşılabilir. Ayrıca sonuçların birden fazla örneklem grubunda denenerek elde edilmesi de araştırmanın iç geçerliğini artırmaktadır.

- Faktör yapısı belirlenen ölçekten elde edilen verilerin ebeveynlerin cinsiyetine göre fark oluşturup oluşturmadığı alt gruplarda normallik varsayımı karşılanamadığından Mann Whitney U Testi ile belirlenmiştir. Mann Whitney U Testi, parametrik test varsayımları karşılanamadığında iki grubun 
ölçülen özellik bakımından farklı olup olmadığını test etmede kullanılır (Büyüköztürk, Çokluk ve Köklü, 2010).

- CETÖ'den elde edilen verilerin öğrenim durumuna göre manidar fark içerip içermediği alt gruplarda normallik varsayımı karşılanamadığından Kruskal Wallis Varyans Analiziyle kontrol edilmiştir. Kruskal Wallis Varyans Analizi, parametrik test varsayımları karşılanamadığında ikiden fazla grubun ölçülen özellik bakımından farklı olup olmadığını test etmede kullanılır (Büyüköztürk, Çokluk ve Köklü, 2010).

- CETÖ’den elde edilen verilerle Ebeveynler İçin Cinsel İletişim Ölçeği'nden elde edilen veriler arasındaki ilişkiler dağılımların normal olması nedeniyle Pearson'un Momentler Çarpımı Korelasyonu ile incelenmiştir. Pearson'un Momentler Çarpımı Korelasyonu, parametrik test varsayımlarının karşılanabildiği durumlarda iki veya daha çok değişken arasındaki ilişkinin yönünü ve miktarını belirlemede kullanılır (Büyüköztürk, Çokluk ve Köklü, 2010). Ayrıca araştırmada CETÖ ile Toplumsal Cinsiyet Algısı Ölçeği (Altınova ve Duyan, 2013) arasındaki ilişkiler de incelenmiştir. Cinsel Eğitimde Kullanılan İletişim Dili Ölçeği ve Toplumsal Cinsiyet Algısı Ölçeği farklı örneklem gruplarında kullanıldığından örneklem sayısı analizlerde farklılık göstermiştir.

\section{Bulgular}

Araştırmada cinsel eğitime yönelik tutum ölçeği geliştirilmesi, geçerlilik ve güvenilirliklerine ilişkin bilgi toplanması amaçlanmıştır. Aşağıda elde edilen bulgular verilmiştir.

\section{Cinsel Eğitime Yönelik Tutum Ölçeğinin Geçerlilik ve Güvenilirliğine İlişkin Bulgular}

55 maddelik denemelik formun ön güvenilirliği Cronbach'ın $\alpha$ katsayısıyla 0,90 olarak hesaplanmıştır. Elde edilen iç tutarlılık katsayısına göre 55 maddelik formdan elde edilen sonuçların güvenilir olduğu yorumu yapılmıştır. Denemelik formun güvenilirliğinin hesaplanmasının ardından verilerin AFA'ya uygun olup olmadığı KMO ve Barlett küresellik testiyle incelenmiştir. KMO değerinin 0,80 olduğu; Barlett küresellik testinden elde edilen sonuçlara göre ki-kare $\left(\chi^{2}=3979\right)$ değerinin .01 düzeyinde manidar olduğu belirlenmiştir. $\mathrm{Bu}$ sonuç, verilerin çok değişkenli normal dağılımdan geldiğini ve faktör analizinin normallik sayıltısını sağladığını göstermektedir.

AFA'dan elde edilen birikinti grafiği Şekil 1'de verilmiştir.
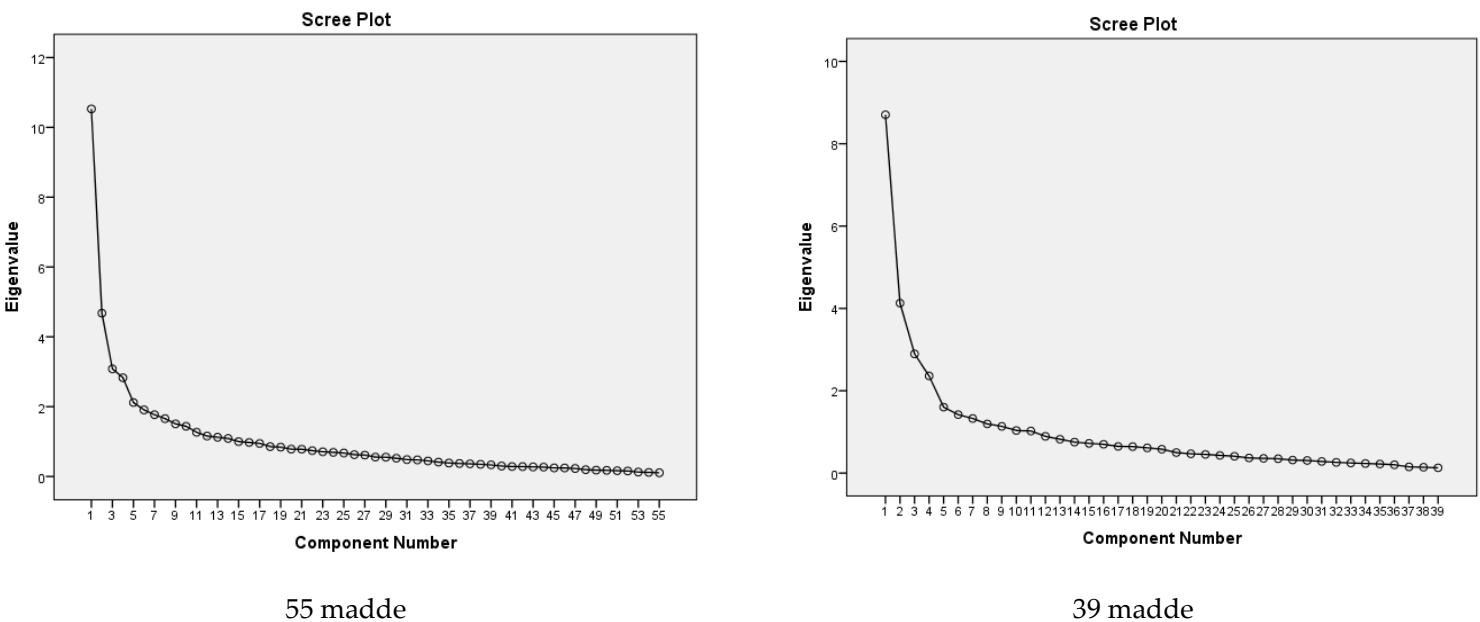

Şekil 1. Birikinti grafiğ

Şekil 1 incelendiğinde 55 ve 39 maddenin kullanılarak gerçekleştirildiği iki analizde de beşinci noktadan sonra eğimin azaldığı görülmektedir. Beşinci noktadan sonra eğimin azalması ölçülen özelliğin dört faktörlü bir yapı olabileceğini düşündürmektedir. AFA yapılırken birikinti grafiği her ne kadar dört faktörlü bir yapı gösteriyor olsa da veriler üzerinde altı, beş ve dört faktörlü olarak AFA tekrarlanarak uygulanmış, bu analizler sırasında çeşitli döndürme teknikleri denenmiştir. Tabachnick ve Fidell (2001) ölçülen yapı kararlı ve tutarlı ise hangi döndürme tekniği kullanılırsa kullanılsın sonucun değişmediğini belirtmiştir. Bu analizler 
sonucunda dört faktörlü yapıda tüm döndürme tekniklerinde ilgili maddelerin bir arada kümelendiği görülmüştür. Yapının dört faktörlü çok bileşenli olduğuna karar verilerek sonuçlar yeniden gözden geçirilmiştir.

Analizler sırasında 16 madde yüksek faktör yük değeri vermemesi nedeniyle analizden çıkarılmıştır. Maddelerin çıkarılmasında en düşük faktör yük değeri veren maddeden başlayarak çıkarma işlemi yapılmış, her çıkarma işleminden sonra faktör analizi tekrarlanmıştır. 55 maddelik denemelik formdan 16 maddenin çıkarılmasıyla 39 maddenin nihai formda kalabileceğine karar verilmiştir. 39 maddelik nihai formun dört faktörlü olarak analiz edilmesinden elde edilen bulgular aşağıda verilmiştir. Bu sonuçlarda varimax döndürme tekniği kullanılmıştır. Maddeler diğer döndürme tekniklerinde de benzer kümelenmiştir. AFA sonuçları aşağıda verilmiştir.

Tablo 3'te faktörlere ait öz değerler ile açıkladıkları varyanslar ve açılanan toplam varyans verilmiştir.

Tablo III

AFA Sonuçlarına İlişkin Öz Değerler ve Açılanan Varyans

\begin{tabular}{llc}
\hline Faktör 1 & Öz değeri & 8.70 \\
& Açıkladığı varyans & 22.31 \\
& Açıklanan toplam varyans & 22.31 \\
\hline Faktör 2 & Öz değeri & 4.1 \\
& Açıkladığı varyans & 10.58 \\
& Açıklanan toplam varyans & 32.90 \\
\hline Faktör 3 & Öz değeri & 2.8 \\
& Açıkladığı varyans & 7.42 \\
\hline Faktör 4 & Açıllanan toplam varyans & 40.32 \\
& Öz değeri & 2.3 \\
& Açıkladığı varyans & 6.04 \\
\hline
\end{tabular}

Tablo 3'te AFA sonuçlarına göre faktörlerin öz değerleri, açıkladıkları varyans ve açıklanan toplam varyans verilmiştir. AFA sonucuna göre birinci faktörün öz değeri 8.70, açıkladığ1 varyans 22.31'dir; ikinci faktörün öz değeri 4.1, açıkladığı varyans 10.58 'dir; üçüncü faktörün öz değer, 2.8, açıkladığı varyans 7.42' dir ve dördüncü faktörün öz değeri 2.3, açıkladığı varyans $6.04^{\prime}$ tür. Açıllanan toplam varyans $46.37^{\prime}$ dir. Çok faktörlü yapılarda açıklanan toplam varyansın \%40-\%60 arasında olması yeterli kabul edilmektedir (Çokluk, Şekercioğlu ve Büyüköztürk, 2010). Tablo 4'te 39 maddelik denemelik formda yer alan maddelerin AFA sonuçlarına göre faktör yük değerleri verilmiştir. Tabloda faktör yük değerleri 0.30 ' dan daha küu̧ük değerler, ilgili faktörde yüksek yük değeri vermemesi nedeniyle gösterilmemiştir.

Tablo IV

39 Maddelik Nihai Formda Yer Alan Maddelerin Faktör Yük Değerleri

\begin{tabular}{|c|c|c|c|c|c|c|c|c|c|}
\hline \multirow[b]{2}{*}{ Madde no } & \multicolumn{4}{|c|}{ Faktör } & \multicolumn{5}{|c|}{ Faktör } \\
\hline & 1 & 2 & 3 & 4 & Madde no & 1 & 2 & 3 & 4 \\
\hline 35 & 0.78 & & & & 4 & & 0.50 & & \\
\hline 36 & 0.78 & & & & 3 & & 0.47 & & \\
\hline 34 & 0.71 & & & & 11 & & 0.46 & & \\
\hline 39 & 0.69 & & & & 30 & & & 0.72 & \\
\hline 52 & 0.66 & & & & 31 & & & 0.71 & \\
\hline 40 & 0.66 & & & & 27 & & & 0.66 & \\
\hline 37 & 0.65 & & & & 32 & & & 0.60 & \\
\hline 54 & 0.64 & & & & 28 & & & 0.60 & \\
\hline 53 & 0.64 & & & & 29 & & & 0.56 & \\
\hline 51 & 0.64 & & & & 26 & & & 0.54 & \\
\hline 55 & 0.44 & & & & 47 & & & 0.44 & \\
\hline 13 & & 0.72 & & & 2 & & & & 0.71 \\
\hline 10 & & 0.72 & & & 1 & & & & 0.67 \\
\hline 12 & & 0.71 & & & 45 & & & & 0.60 \\
\hline 14 & & 0.71 & & & 7 & & 0.37 & & 0.60 \\
\hline 15 & & 0.68 & 0.37 & & 48 & & & & 0.60 \\
\hline 8 & & 0.67 & & & 25 & & & & 0.56 \\
\hline 17 & & 0.58 & 0.41 & & 5 & & & & 0.45 \\
\hline & & & & & & & & & \\
\hline
\end{tabular}


Tablo 4'te faktör yük değerleri incelendiğinde, birinci faktörde yer alan 11 maddenin faktör yük değerlerinin 0.78 ile 0.44 arasında olduğu; ikinci faktörde yer alan 12 maddenin faktör yük değerlerinin 0.72 ile 0.46 arasında olduğu, üçüncü faktörde yer alan sekiz maddenin faktör yük değerlerinin 0.72 ile 0.44 arasında olduğu; dördüncü faktörde yer alan sekiz maddenin faktör yük değerlerinin 0.71 ile 0.44 arasında olduğu görülmektedir. Alan yazında bir maddenin faktör yük değerinin 0.30 'dan daha büyük olması yönünde bir görüş vardır. En az 200 kişilik bir örneklemde faktör yük değerinin 0.40 ve üzerinde olması gerektiğine ilişkin bilgiler de vardır (Çokluk, Şekercioğlu ve Büyüköztürk, 2010). Bu bilgiler ölçüt olarak kullanıldığında 39 maddenin ölçekte kalmasına karar verilmiştir. Daha sonra elde edilen veriler üzerinde DFA uygulanmış ve buna ilişkin bulgular aşağıda verilmiştir.

Şekil 2'de DFA sonuçlarından elde edilen standardize sonuçlar ve Şekil 3'te $t$ değerlerini içeren path diyagramları verilmiştir.

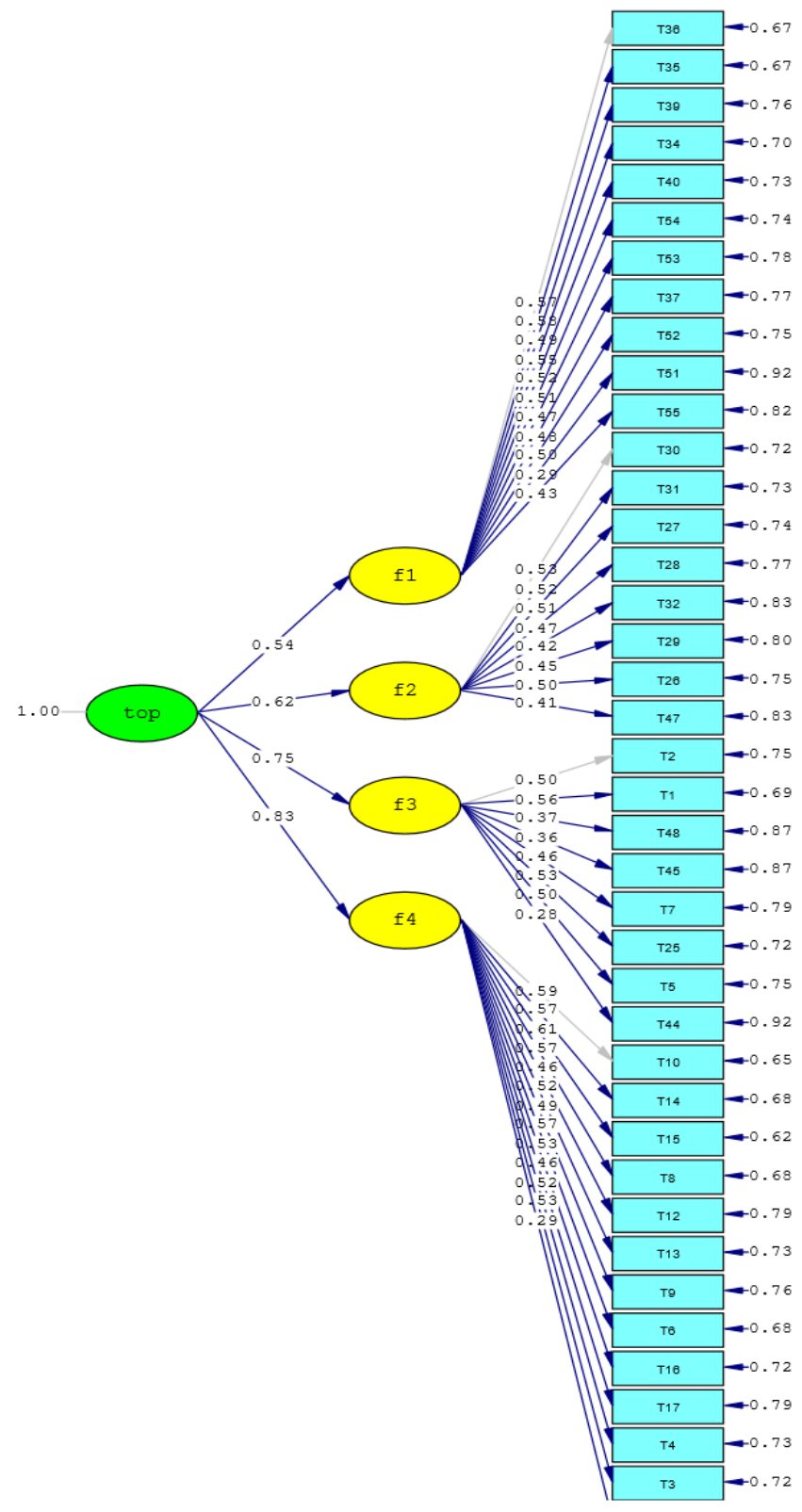

Şekil 2. Cinsel Eğitime Yönelik Tutum Ölçeği'nin DFA analizi sonucunda elde edilen standardize sonuçlar 


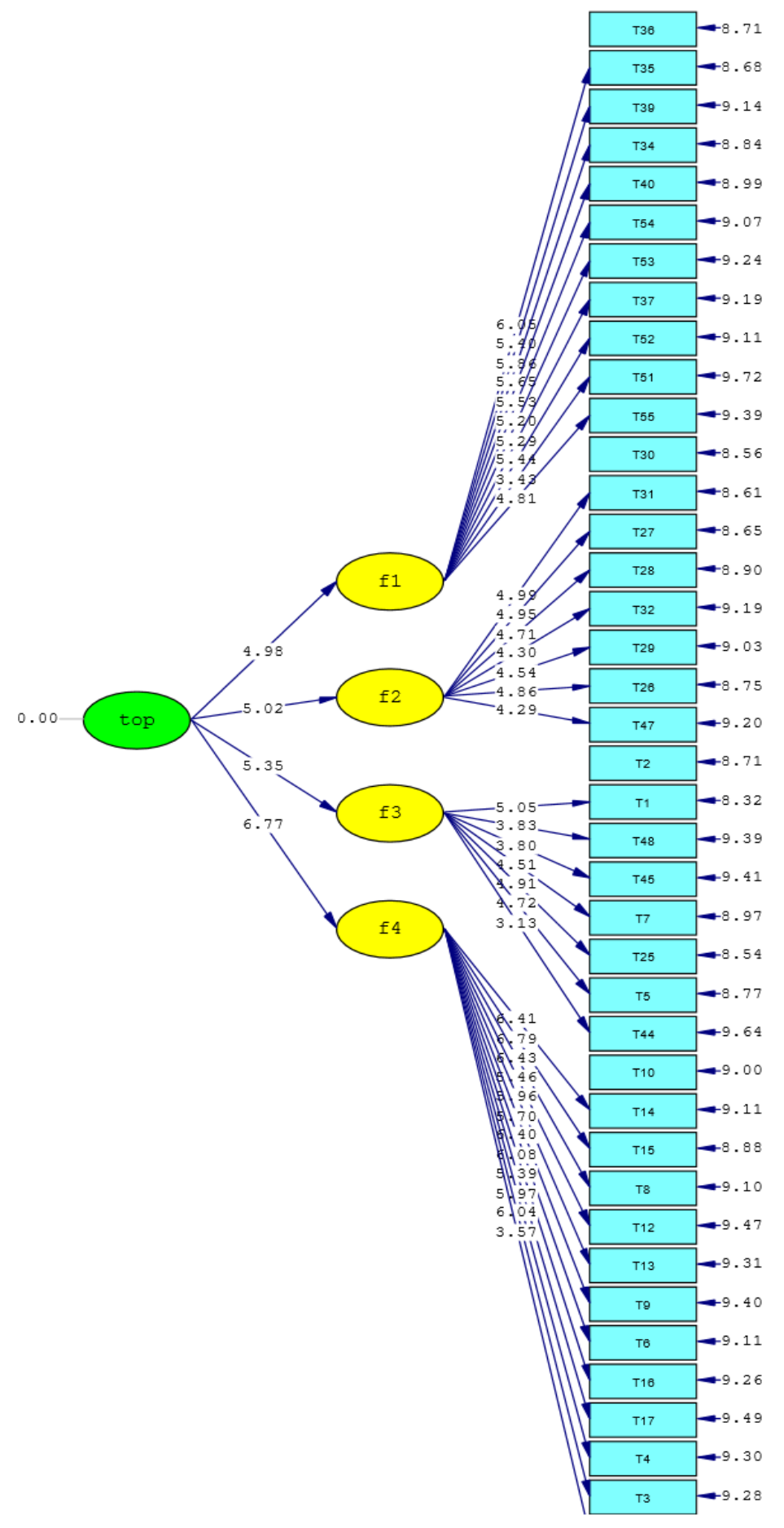

Şekil 3. Cinsel Eğitime Yönelik Tutum Ölçeği'nin DFA analizi sonucunda elde edilen t değerleri

Şekil 2 ve 3 incelendiğinde, t değerlerinin 3.13 ile 6.79 arasında değiştiği görülmektedir. Analizde $t$ değeri gizil değişkenlerin gözlenen değişkenleri açıklama durumuna ilişkin bilgi vermektedir ve t değeri 2.56 'y1 aşması durumunda .01 düzeyinde manidar olduğu söylenebilir. DFA'da $t$ değerinin manidar olmadığı durumlarda ilgili maddenin ölçekten çıkarılması gerekir (Çokluk, Şekercioğlu ve Büyüköztürk, 2010). Bu bilgiden yararlanılarak tüm maddelerin ölçekte kalmasına karar verilmiştir. Ölçeğin yapısı hakkında karar verildikten sonra ölçme aracı üçüncü bir çalışma grubunda tekrar denenmiş ve sonuçlar kontrol edilmiştir. Tablo 5'te ikinci ve üçüncü çalışma grubundan elde edilen verilerin DFA sonucuna göre uyum iyiliği indisleri yer almaktadır. 
Tablo V

DFA Sonucunda Elde Edilen Uyum İyiliği İndisleri

\begin{tabular}{|c|c|c|c|}
\hline & Ölçütler & $\begin{array}{c}\text { İkinci Çalışma Grubu } \\
(\mathrm{N}=199)\end{array}$ & $\begin{array}{c}\text { Üçüncü Çalışma Grubu } \\
(\mathrm{N}=200)\end{array}$ \\
\hline$\chi^{2}$ & --- & 549.10 & 3467 \\
\hline sd & --- & 736 & 805 \\
\hline$\chi^{2} / \mathrm{sd}$ & $\begin{array}{l}<3 \text { ise mükemmel uyum } \\
\leq 5 \text { ise kabul edilebilir uyum }\end{array}$ & 0.74 & 4.30 \\
\hline RMSEA & $\begin{array}{l}<0.07 \text { ise iyi uyum } \\
\leq 0.07-0.08 \text { ise kabul edilebilir uyum }\end{array}$ & 0.00 & 0.07 \\
\hline SRMR & $\begin{array}{l}<0.05 \text { ise mükemmel uyum } \\
\leq 0.08 \text { ise iyi uyum }\end{array}$ & 0.05 & 0.08 \\
\hline NNFI & $\begin{array}{l}\geq 0.95 \text { ise mükemmel uyum } \\
\geq 0.90 \text { ise iyi uyum }\end{array}$ & 1.00 & 0.90 \\
\hline CFI & $\begin{array}{l}\geq 0.95 \text { ise mükemmel uyum } \\
\geq 0.90 \text { ise iyi uyum }\end{array}$ & 1.00 & 0.90 \\
\hline
\end{tabular}

Tablo 5'te DFA sonucunda elde edilen değerlerle birlikte karşılamaları gereken ölçütler (Brown, 2006; Kline, 2005; Steiger, 2007; Tabachnick ve Fidell, 2001) verilmiştir. DFA sonuçlarına göre ölçme aracından elde edilen veriler kabul edilebilir uyum göstermiştir.

Tablo 6'da Cinsel Eğitime Yönelik Tutum Ölçeği'nin alt boyutlarına ve toplamına ilişkin güvenilirlik katsayıları verilmiştir.

Tablo VI

Cinsel Ĕ̆gitime Yönelik Tutum Ölçeği Alt Boyutlarına Ve Toplamına İlişkin İç Tutarlılık Katsayıları

\begin{tabular}{lcc}
\hline Ölçek/Alt Boyut & İkinci uygulama & Üçüncü uygulama \\
\hline Kaçınma & 0.88 & 0.93 \\
Gerekliliğine inanma & 0.87 & 0.89 \\
Profesyonel destek ve farklılıklara saygı & 0.80 & 0.85 \\
Ebeveynin rolü & 0.77 & 0.85 \\
CETÖ Toplam & 0.90 & 0.94 \\
\hline
\end{tabular}

CETÖ'nün iç tutarlılığı Cronbach'ın $\alpha$ katsayısı kullanılarak hesaplanmış ve alt boyutların güvenilirliğinin 0.77 ile 0.93 arasında olduğu belirlenmiştir. Tüm maddelerden elde edilen iç tutarlılık katsayısı ise ikinci uygulamada 0.90, üçüncü uygulamada 0.94 olarak hesaplanmıştır. Bu sonuçlar ölçme aracından elde edilen sonuçların güvenilir olduğunu göstermektedir.

Ölçeğin alt boyutları arasındaki ilişkiler dağılımın normal olması nedeniyle Pearson Momentler Çarpımı Korelasyonu ile incelenmiş ve sonuçları Tablo 7 'de verilmiştir.

Tablo VII

Ölçeğin Alt Faktörleri Arasındaki İlişkiler

\begin{tabular}{|c|c|c|c|c|}
\hline & Kaçınma & Gerekliliğine inanma & $\begin{array}{l}\text { Profesyonel destek ve } \\
\text { farklılıklara sayg1 }\end{array}$ & Ebeveynin rolü \\
\hline Kaçınma & 1.00 & & & \\
\hline Gerekliliğine inanma & $0.27^{*}$ & 1.00 & & \\
\hline $\begin{array}{l}\text { Profesyonel destek ve farklılıklara } \\
\text { sayg1 }\end{array}$ & $0.28^{*}$ & $0.41^{*}$ & 1.00 & \\
\hline Ebeveynin rolü & $0.32^{*}$ & $0.42^{*}$ & $0.35^{*}$ & 1.00 \\
\hline CETÖ Toplam & $0.79^{*}$ & $0.69^{*}$ & $0.63^{*}$ & $0.68^{*}$ \\
\hline
\end{tabular}

Ölçeğin alt boyutları arasında .01 düzeyinde manidar ilişkiler olduğu gözlenmiştir. Ölçeğin alt boyutları arasındaki ilişkiler orta düzeydedir ancak her alt boyutun toplam puanla olan ilişkisi güçlüdür.

\section{Anne ve Babaların Cinsel Eğitime Yönelik Tutumlarına İlişkin Bulgular}

Anne babaların cinsel eğitime yönelik tutumlarını daha iyi anlamak için ölçeğin alt boyutlarından ve tümünden aldıkları puanlara ilişkin betimsel istatistikler hesaplanmıştır. Annelerin ve babaların ölçekten aldıkları puanlar arasındaki farkın manidar olup olmadığı bazı alt gruplarda dağılımın normalliği sağlanamadığından Mann Whitney U Testiyle incelenmiş ve Tablo 8'de bulgular sunulmuştur. 
Tablo VIII

Anne ve Babaların CETÖ'den ve Alt Boyutlarından Aldıkları Puanlara İlişkin Betimsel İstatistikler ve Mann Whitney U Testi Sonuçları

\begin{tabular}{|c|c|c|c|c|c|c|}
\hline & & $\mathrm{n}$ & $\bar{X}$ & Sx & $\mathrm{U}$ & $\mathrm{p}$ \\
\hline \multirow{2}{*}{ Kaçınma } & Anne & 119 & 31.09 & 7.79 & \multirow{2}{*}{4673} & \multirow{2}{*}{.82} \\
\hline & Baba & 80 & 30.98 & 7.68 & & \\
\hline \multirow{2}{*}{ Gerekliliğine inanma } & Anne & 119 & 44.50 & 4.50 & \multirow{2}{*}{4454} & \multirow{2}{*}{.43} \\
\hline & Baba & 80 & 44.02 & 4.63 & & \\
\hline \multirow{2}{*}{$\begin{array}{l}\text { Profesyonel destek ve } \\
\text { farklılıklara sayg1 }\end{array}$} & Anne & 119 & 28.63 & 3.14 & \multirow{2}{*}{4732} & \multirow{2}{*}{.94} \\
\hline & Baba & 80 & 28.20 & 4.08 & & \\
\hline \multirow{2}{*}{ Ebeveynin rolü } & Anne & 119 & 26.52 & 3.75 & \multirow{2}{*}{4287} & \multirow{2}{*}{.23} \\
\hline & Baba & 80 & 25.70 & 4.42 & & \\
\hline \multirow{2}{*}{ CETÖ Toplam } & Anne & 119 & 130.76 & 13.7 & \multirow{2}{*}{4442} & \multirow{2}{*}{.42} \\
\hline & Baba & 80 & 128.91 & 15.0 & & \\
\hline
\end{tabular}

Tablo 8' deki sonuçlar incelendiğinde, anne ve babaların cinsel eğitime yönelik tutumları arasında manidar bir fark olmadığı görülmektedir ( $\mathrm{p}>.05)$.

\section{Ebeveynlerin Öğrenim Durumları ve Cinsel Eğitime Yönelik Tutumlarına İlişkin Bulgular}

Ebeveynlerin öğrenim durumuna göre cinsel eğitime yönelik tutumları arasında fark olup olmadı̆̆ bazı alt gruplarda dağılımın normal olmaması nedeniyle Kruskal Wallis H testi ile incelenmiştir. Elde edilen bulgular Tablo 9' da verilmiştir.

Tablo IX

Farklı öğrenim düzeyindeki ebeveynlerin cinsel eğitime yönelik tutum puanlarına ilişkin Kruskal Wallis H Testi sonuçları

\begin{tabular}{|c|c|c|c|c|c|c|c|}
\hline Ölçek/Alt Boyut & Son mezuniyet & $\mathrm{n}$ & $\bar{X}$ & Sx & $\chi^{2}$ & $\mathrm{p}$ & Fark \\
\hline \multirow{3}{*}{ Kaçınma } & İlk ve ortaokul & 53 & 29.15 & 7.28 & \multirow{3}{*}{11.27} & \multirow{3}{*}{.004} & \multirow{3}{*}{$\begin{array}{l}1 \text { ve } 3 \\
2 \text { ve } 3\end{array}$} \\
\hline & Lise & 56 & 29.91 & 8.03 & & & \\
\hline & Yükseköğretim & 90 & 32.95 & 7.42 & & & \\
\hline \multirow{3}{*}{$\begin{array}{l}\text { Gerekliliğine } \\
\text { inanma }\end{array}$} & İlk ve ortaokul & 53 & 43.86 & 3.27 & \multirow{3}{*}{11.06} & \multirow{3}{*}{.004} & \multirow{3}{*}{$\begin{array}{l}1 \text { ve } \\
2 \text { ve } 3\end{array}$} \\
\hline & Lise & 56 & 43.62 & 5.48 & & & \\
\hline & Yükseköğretim & 90 & 45.04 & 4.50 & & & \\
\hline \multirow{3}{*}{$\begin{array}{l}\text { Profesyonel } \\
\text { destek } \\
\text { farklılıklara } \\
\text { sayg1 }\end{array}$} & İlk ve ortaokul & 53 & 28.92 & 3.20 & \multirow{3}{*}{11.96} & \multirow{3}{*}{.003} & \multirow{3}{*}{2 ve 3} \\
\hline & Lise & 56 & 27.17 & 3.83 & & & \\
\hline & Yükseköğretim & 90 & 29.06 & 3.32 & & & \\
\hline \multirow{3}{*}{ Ebeveynin rolü } & İlk ve ortaokul & 53 & 26.11 & 3.98 & \multirow{3}{*}{6.48} & \multirow{3}{*}{.038} & \multirow{3}{*}{2 ve 3} \\
\hline & Lise & 56 & 24.92 & 4.99 & & & \\
\hline & Yükseköğretim & 90 & 27.10 & 3.09 & & & \\
\hline \multirow{3}{*}{ CETÖ Toplam } & İlk ve ortaokul & 53 & 128.05 & 12.21 & \multirow{3}{*}{12.90} & \multirow{3}{*}{.002} & \multirow{3}{*}{$\begin{array}{l}1 \text { ve } 2 \\
2 \text { ve } 3\end{array}$} \\
\hline & Lise & 56 & 125.64 & 16.35 & & & \\
\hline & Yükseköğretim & 90 & 130.15 & 12.75 & & & \\
\hline
\end{tabular}

* 1: İlk ve ortaokul mezunu, 2: Lise mezunu, 3: Yükseköğretim mezunu

Tablo 9 incelendiğinde öğrenim düzeyine bağlı olarak cinsel eğitime yönelik tutumlarda istatistiksel olarak manidar bir farkın olduğu görülmektedir ( $\mathrm{p}<.05)$. Bu fark Kaçınma faktöründe, Gerekliliğine İnanma faktöründe ve toplam puanlarda ilk ve ortaokul mezunları ile yükseköğretim mezunları arasında, aynı zamanda lise mezunu ile yükseköğretim mezunları arasındadır. Profesyonel Destek ve Farklılıklara Sayg1 faktörü ve Ebeveynin Rolü faktöründe ise yükseköğretim ve lise mezunları arasında cinsel eğitme yönelik tutumlar arasında manidar bir fark vardır. Bu bulgulara dayalı olarak, yükseköğretim mezunlarının cinsel eğitime yönelik tutumlarının daha olumlu olduğu söylenebilir.

\section{Toplumsal Cinsiyet Algısı ve Cinsel Eğitime Yönelik Tutumlara İlişkin Bulgular}

CETÖ'den elde edilen verilerle Ebeveynler İçin Cinsel İletişim (Cİ) Ölçeği ve Toplumsal Cinsiyet Algisı (TCA) Ölçeği'nden elde edilen veriler arasındaki ilişkiler Tablo 10'da verilmiştir. Cİ ikinci çalışma grubundan elde edilen verilerle, TCA ise üçüncü çalışma grubundan elde edilen verilerle çözümlendiğinden örneklem sayıları farklılık göstermektedir. 
Tablo X

CETÖ ile Cİ ve TCA Ölçekleri Arasındaki İlişkiler

\begin{tabular}{|c|c|c|c|c|c|c|}
\hline \multirow[b]{2}{*}{ Ölçek/Alt Boyut } & & \multicolumn{5}{|c|}{ Cinsel Eğitime Yönelik Tutum Ölçeği } \\
\hline & & Kaçınma & $\begin{array}{c}\text { Gerekliliğine } \\
\text { inanma }\end{array}$ & $\begin{array}{l}\text { Profesyonel destek ve } \\
\text { farklılıklara sayg1 }\end{array}$ & Ebeveynin rolü & Toplam \\
\hline \multirow{3}{*}{ Cİ Ölçeği } & $\mathrm{r}$ & -0.047 & $0.325^{*}$ & $0.251^{*}$ & $0.296^{*}$ & $0.220^{*}$ \\
\hline & $\mathrm{p}$ & .519 & .000 & .000 & .000 & .000 \\
\hline & $\mathrm{N}$ & 199 & 199 & 199 & 199 & 199 \\
\hline \multirow{3}{*}{ TCA Ölçeği } & $\mathrm{r}$ & $0.418^{*}$ & $0.542^{*}$ & $0.467^{*}$ & $0.400^{*}$ & $0.540^{*}$ \\
\hline & $p$ & .000 & .000 & .000 & .000 & .000 \\
\hline & $\mathrm{N}$ & 200 & 200 & 200 & 200 & 200 \\
\hline
\end{tabular}

Cİ Ölçeği ile Gerekliliğine İnanma ( $\mathrm{r}=0.325, \mathrm{p}<.01)$, Profesyonel Destek ve Farklılıklara Sayg1 ( $\mathrm{r}=0.251$, $\mathrm{p}<.01)$, Ebeveyn Rolü faktörleri $(\mathrm{r}=0.296, \mathrm{p}<.01)$ ve toplam puanları $(\mathrm{r}=0.220, \mathrm{p}<.01)$ arasında pozitif yönde manidar ilişkiler olduğu belirlenmiştir. Bu bulgu anne babaların cinsel eğitime yönelik tutumlarının cinsel eğitim sırasında kullandıkları iletişimlerini etkileyebileceğini düşündürmektedir.

Toplumsal Cinsiyet Algısı Ölçeği ile Gerekliliğine İnanma $(\mathrm{r}=0.542, \mathrm{p}<.01)$, Profesyonel Destek ve Farklılıklara Sayg1 $(\mathrm{r}=0.467, \mathrm{p}<.01)$, Ebeveyn Rolü faktörleri $(\mathrm{r}=0.400, \mathrm{p}<.01)$ ve toplam puanları $(\mathrm{r}=0.54, \mathrm{p}<.01)$ arasında pozitif yönde manidar ilişkiler olduğu belirlenmiştir. Bu bulgu, eşitlikçi toplumsal cinsiyet algısı ile cinsel eğitime yönelik olumlu tutumlar; eşitlikçi olmayan toplumsal cinsiyet algısı ile cinsel eğitime yönelik olumsuz tutumlar arasında ilişkiler olduğunu göstermektedir.

\section{Ebeveynlerin Çocuklarının Cinsel Eğitim Almalarına Göre Cinsel Eğitime Yönelik Tutumlarına İlişkin Bulgular}

Bir ölçme aracının geçerliğinin belirlenmesinde bireylerin gerçek yaşamda ölçülen özellikle ilgili davranışlarını incelemek ve ölçekten elde edilen puanlarla gerçek yaşamda ölçülen özellikle ilgili durumlar arasındaki ilişkileri belirlemek geliştirilen ölçme aracının yapı geçerliğine ilişkin kanıtlar sunar (Janda, 1998). $\mathrm{Bu}$ nedenle anne ve babaların "Çocuğunuzun cinsel eğitim almasını ister misiniz?" sorusuna verdikleri yanıtlara göre Cinsel Eğitime Yönelik Tutum Ölçeğinden aldıkları puanlar arasındaki farklar incelenmek istenmiş ancak iki gruptaki birey sayılarının çok farklı olması nedeniyle burada yalnızca ortalama ve standart sapma değerleri incelenmiştir. Elde edilen sonuçlar Tablo 11'de verilmiştir.

\section{Tablo XI}

Anne Babaların Çocuklarının Cinsel Ĕ̆itim Alması Hakkındaki Görüşlerine Göre Cinsel Eğitime Yönelik Tutum Ölçeği Puanlarının Ortalama ve Standart Sapma Değerleri

\begin{tabular}{lccc}
\hline İsteme Durumu & Say1 & $\bar{X}$ & Standart sapma \\
\hline İsterim & 144 & 128.4 & 14.7 \\
İstemem & 56 & 102.6 & 14.5 \\
\hline
\end{tabular}

Tablo 11 incelendiğinde çocuklarının cinsel eğitim almasını isteyen ebeveynlerin Cinsel Eğitime Yönelik Tutum puanlarının ortalaması $(\bar{X}=128.4)$ çocuklarının cinsel eğitim almasını istemeyen ebeveynlerin tutum puanlarının ortalamasından $(\bar{X}=102.6)$ daha yüksektir. Bu durumda çocuğunun cinsel eğitim almasını isteyen anne ve babaların cinsel eğitime yönelik tutumlarının daha olumlu olması beklenir. Elde edilen sonuçlar çocuğunun cinsel eğitim almasını isteyen anne ve babalarının tutumlarının daha olumlu olduğuna ilişkin bilgi sunmaktadır. Elde edilen bu bulgular ölçme aracının ölçmeyi amaçladığı özelliği ölçebildiğine ilişkin kanıt oluşturmaktadır. Cinsel Eğitime Yönelik Tutum Ölçeği'ne ilişkin nihai bulgular Tablo 12' de özetlenmiştir.

Tablo XII

Cinsel Eğitime Yönelik Tutum Ölçeği'nin Alt Boyutları ve Maddelere İlişkin Bilgiler

\begin{tabular}{lll}
\hline Alt Boyut & Maddeler & Açıllama \\
\hline $\begin{array}{l}\text { Profesyonel destek ve } \\
\text { farklılıklara saygı }\end{array}$ & 1-8. maddeler & Ters madde yoktur. Bu alt boyuttan alınabilecek en düşük puan 8, en yüksek puan 32'dir. \\
$\begin{array}{l}\text { Ebeveynin rolü } \\
\text { Gerekliliğine inanma }\end{array}$ & $\begin{array}{l}\text { 9-16. maddeler } \\
\text { 17-28. } \\
\text { maddeler }\end{array}$ & $\begin{array}{l}\text { Ters madde yoktur. Bu alt boyuttan alınabilecek en düşük puan 8, en yüksek puan 32' dir. } \\
\text { Ters madde yoktur. Bu alt boyuttan alınabilecek en düşük puan 12, en yüksek puan 48'dir. }\end{array}$ \\
$\begin{array}{l}\text { Kaçınma } \\
\text { maddeler }\end{array}$ & $\begin{array}{l}\text { Tüm maddeler ters puanlanmaktadır. Toplam puana katkısı alınırken dikkate alınmalıdır. } \\
\text { Bu alt boyuttan alınabilecek en düşük puan 11, en yüksek puan 44'tür. }\end{array}$ \\
\hline
\end{tabular}


Cinsel eğitime yönelik tutum ölçeği 39 maddeden oluşmaktadır. Ölçekte birinci faktörde 8 madde, ikinci faktörde 8 madde, üçüncü faktörde 12 madde ve dördüncü faktörde 11 madde vardır. Ölçekten alınabilecek en düşük puan 39, en yüksek puan 156'dır. Dört faktörlü 39 maddelik ölçeğin maddelerinden elde edilen puanlar toplanmaktadır. Toplam puanın yüksek olması anne ve babanın cinsel eğitime yönelik tutumunun olumlu olduğunu göstermektedir.

Kaçınma faktöründe yer alan maddelerin tümünün olumsuz yargı içermesi nedeniyle uygulama sırasında o maddelerin ölçeğin sonunda bulunmasında fayda vardır. Toplam 39 maddeden oluşan ölçeğin iç tutarlılık katsayısı 0,90 olarak hesaplanmıştır. Araştırma sonuçlarına göre ölçeğin sonuçlarının geçerli bulgular üretebileceğine karar verilmiştir. Ölçeğin alt boyutları arasında orta düzeyde manidar ilişkiler olduğu belirlenmiştir.

\section{Sonuç ve Tartışma}

$\mathrm{Bu}$ araştırmada ebeveynlerin cinsel eğitime yönelik tutumlarını belirlemek amacıyla bir ölçme aracının geliştirilmesi amaçlanmıştır. Geliştirilen ölçme aracının güvenilir ve geçerli sonuçlar üretebileceğine ilişkin kanıtlar araştırmanın bulgular bölümünde sunulmuştur. CETÖ'den elde edilen verilerle gerçekleştirilen diğer analizler sonucunda aşağıdaki sonuçlara ulaşılmıştır.

- Ebeveynlerin cinsiyetleri cinsel eğitime yönelik tutumlarında bir farka yol açmamaktadır.

- Ebeveynlerin öğrenim düzeyleri cinsel eğitime yönelik tutumlarında manidar bir farka yol açmaktadır. Araştırmada yükseköğretim mezunu olan anne babaların cinsel eğitime daha olumlu tutumlar geliştirdiği belirlenmiştir. Bu durum cinsel eğitimle ilgili bilgi düzeyinin daha olumlu tutumlara yol açabileceğini düşündürmüştür.

- Ebeveynlerin cinsel eğitime yönelik tutumları ile cinsel eğitimde kullandıkları iletişim dili arasında pozitif yönde ilişkilerin olduğu, cinsel eğitime yönelik tutumların anne babaların cinsel eğitimde kullandıkları iletişim dilini değiştirebileceği sonucuna ulaşılmıştır.

- Bu araştırmada eşitlikçi toplumsal cinsiyet algısı ile cinsel eğitime yönelik olumlu tutumlar, eşitlikçi olmayan toplumsal cinsiyet algısı ile cinsel eğitime yönelik olumsuz tutumlar arasında ilişki olduğu belirlenmiştir.

Çocuklara cinsel eğitimi verme sorumluluğunun çoğunu ebeveynlerin üstlendiği düşünülmektedir. Bu görev çoğu zaman zor bir görevdir ve ebeveynlerin çocukların cinsellikle ilgili yetkinliklerinin gelişimini kolaylaştırmak ve organize etmek için yardıma gereksinim duyduklarını gösteren veriler mevcuttur. Bu süreci etkileyen birçok faktör söz konusudur. Cinsel eğitimle ilgili alanyazında cinsel eğitime yönelik tutum ve davranışları etkileyen faktörler arasında genetik, sosyo-ekonomik durum, aile yapısı ve yönetimi, ebeveynlerin cinsiyeti, iletişim şekli, ebeveynlik tarzı, ebeveyn cinsel eğitim seviyesi; ebeveyn tutumları, değerleri ve inançları gösterilmektedir (Nyarko, Adentwi, Asumeng ve Ahulu, 2014; Pop ve Rusu, 2015). Bu araştırmada, ebeveynlerin cinsel eğitime yönelik tutumlarını belirlemek için geçerli ve güvenilir bir ölçme aracı geliştirilmiş olup, ebeveynlerin tutumları arasındaki fark, ebeveynlerin öğrenim düzeyi, çocuklarının cinsel eğitim alması hakkındaki görüşleri vb. değişkenlerle ilişkisi incelenmiştir.

$\mathrm{Bu}$ araştırmada anne ve babaların cinsel eğitime yönelik tutumları arasında manidar bir fark olmadığı bulunmuştur. Tuğut ve Gölbaşı (2019), okul öncesi dönem çocuğu olan (3-6 yaş) ebeveynlerin cinsel eğitim tutumlarının belirlenmesi ile ilgili yaptıkları çalışma sonucunda anne ve babaların çocuk cinsel eğitimine yönelik tutumlarının benzer olduğunu bulmuşlardır. Eroğlu ve Gölbaşı (2005), cinsel eğitimde ebeveynlerin yeri ile ilgili yaptıkları araştırma sonucunda, anne ve babalar arasında cinsellikle ilgili konularda bilgilerini yeterli bulma durumları açısından önemli bir fark saptamamışlardır. Shin, Lee ve Min (2019), ilkokul döneminde çocuğu olan 360 ebeveynle yaptıkları çalışmada, annelerin cinsel bilgi ve cinsel tutum puanlarının babalarınkinden daha yüksek olduğunu ancak bunun istatistiksel olarak anlamlı olmadığını bulmuşlardır.Ebeveynler ile yürütülen araştırmada, annelerle babaların her ikisinin de en yüksek oranda cinsel eğitime karşı olumlu tutum içinde oldukları bulunmuştur. Annelerle babaların tutumları arasındaki farkın istatistiksel olarak anlamlı olmadığı bulunmuştur (Nagpal ve Fernandes, 2015). Bir başka çalışmada da 
5 yaşında çocuğu olan annelerin de babaların da her iki cinsiyetteki çocuklarılya benzer oranda konuştukları bulunmuştur. Ancak yaş büyüdükçe, bazı alt başlıklarda konuşma oranında farklılık gözlenmiştir (Downie ve Coates, 1999). Ergenlik döneminde çocuğu olan 1179 ebeveyn ile yürütülen araştırmanın sonuçları ebeveynlerin çocuklarının cinsel eğitim gereksiniminin farkında olduklarını ortaya koymaktadır. Anne babaların çocukların cinsel eğitime başlama yaşı hakkındaki görüşleri açısından aralarındaki farkın istatistiksel olarak anlamlı olmadığı; ancak ilk kez regl olma, kadın ve erkek genital organları arasındaki farklar gibi bazı konuların verilme dönemi açısından istatistiksel fark olduğu görülmüştür (Jankovi, Malatestini ve Striehl, 2013). Ebeveynlerin çocuklarının “Ben nereden geldim?" sorusuna verdikleri kaçamak ve yetersiz yanıtlar açısından da anne ve babalar arasında istatistiksel bir fark bulunmamıştır. Ayrıca, vajina, penis ve benzeri cinsel kelimeleri doğru kullanma konusunda da anne baba arasındaki farkın istatistiksel olarak anlamlı olmadığı bulunmuştur (Liu ve Edwards, 2003). Bu araştırma sonuçlarında ve incelenen çalışmaların pek çoğunda, anne ve babaların cinsel eğitime yönelik tutumları arasında anlamlı farka rastlanmamıştır. Yürütülen bu çalışmada anne babaların cinsel eğitimin içeriği ve başlama yaşıyla ilgili aynı görüşte oldukları, bu nedenle tutumlarının da benzer olduğu akla gelmektedir. Ülkemizde Milli Eğitim Bakanlığı tarafından yürütülen resmi bir cinsel eğitim programı bulunmamaktadır. Cinsel eğitimle ilgili konular, müfredat programında, daha çok fen derslerinin içinde yer almaktadır. Bu bilgiler de öğrencilere "cinsel eğitim" adı ile sunulmamaktadır. Çalışma kapsamındaki anneler de babalar da aynı eğitim sistemi içinde yetişmiş ve okullarında gerçek anlamda bir cinsel eğitim almamışlardır. Kız veya erkek öğrenci olmak okulda cinsel eğitim alma yönünde bir farklılık yaratmamaktadır, yeterli veya yetersiz eğitim alma konusunda her iki cinsiyet de eşit durumdadır. Elbette aileyle ilgili farklılıklar olabileceği düşünülebilir ama çalışmadaki anne ve babaların genel tutumunun, toplumun genel tutumuyla paralel olması şaşırtıcı değildir. Derinlemesine düşünüldüğünde çalışma kapsamındaki anne babaların ebeveynleri de cinsel eğitim konusunda okullarda eğitilmemişlerdir. Böylece, cinsel eğitime yönelik tutum geliştirmede ailenin rolünün en aza indirgenmiş olduğu düşünülebilir.

$\mathrm{Bu}$ araştırmada yükseköğrenim mezunu olan ebeveynlerin cinsel eğitime yönelik tutumlarının daha olumlu olduğu sonucuna ulaşılmıştır. Opara ve diğerleri (2010), annelerin cinsel eğitimle ilgili algısını inceledikleri araştırma sonucunda, yükseköğretim mezunu olan kadınların yaklaşık \% 68'i cinsel eğitimi hakkında iyi bilgiye sahip olduğunu, öğrenim düzeyi düştükçe bu oranın azalmaya devam ettiğini bulmuşlardır. Bu çalışma eğitim düzeyi arttıkça, cinsel eğitime yönelik tutumlarının daha olumlu olduğu sonucunu destekler niteliktedir. Nyarko ve diğerleri, (2014), yürüttükleri çalışmada yüksek öğrenim gören ebeveynlerin ortaöğretim ve düşük eğitime sahip olanlara göre cinsel eğitime yönelik daha olumlu bir tutum sergilediklerini bulmuştur. Bir diğer çalışmada da anne babaların cinsel eğitime yönelik genel tutumlarında ve aile içindeki cinsel eğitime yönelik tutumlarında, anne baba eğitim düzeyinin anlamlı farka yol açtı̆̆ bulunmuştur (Liu ve Edwards, 2003). Ebeveynlerin eğitim düzeyinin yüksek olması çocuklarıyla ilgili gelişim, sağlık, eğitim vb. konularda daha duyarlı olmayı sağladığını düşündürmektedir.

Bu araştırmada ebeveynlerin cinsel eğitime yönelik tutumlarıyla, çocuklarıyla cinsel iletişimleri arasında pozitif yönlü bir ilişki olduğu bulunmuştur. Cinsel eğitime yönelik olumlu tutum arttıkça cinsel eğitimde kullanılan iletişimde de beklenen davranışlar artmaktadır. Ebeveynler, çocuklarının cinsel gelişimlerini desteklemeye istekli olmalarına rağmen genellikle bilgi, motivasyon ve onları en iyi sonuçları elde etmelerine yardımcı olabilecek stratejilere gereksinim duymaktadır (Pop ve Rusu, 2015). Ebeveynlerin kapsamlı cinsel eğitim konusundaki bilgi, rahatlık ve tutumları ile cinsel iletişim arasında ilişkinin olumlu olduğu görülmektedir (Byers, Sears ve Weaver, 2008). Ceylan ve Çetin (2015)'in yaptıkları çalışmada, cinsel eğitimin gerekli olduğunu düşünen ebeveynler çocuklarının sordukları soruları nasıl cevaplamaları, çocuklarının meraklarını nasıl gidermeleri gerektiğini bilmediklerini belirtmiştir. Ayrıca, ebeveynler hangi tutum ve davranışları sergilemeleri gerektiğini bilmediklerini, hangi durumda ne yapmaları gerektiği ya da hangi yaşta ne kadar bilgi verilmesi gerektiğini bilmediklerini de eklemişlerdir. Yapılan çalışmalarda da vurgulandığ 1 gibi, ebeveynlerin cinsel eğitimle ilgili olumlu bir tutuma sahip olduklarında konuyla ilgili yetersizliklerini fark ederek çocukla doğru iletişim kurmak için çaba sarf ettikleri söylenebilir. Bu sonuçlardan yola çıkarak cinsel eğitime yönelik olumlu tutumun yeterli olmadığı, anne babaların aynı zamanda bu konularda bilgi gereksinimi olduğunu söylemek gerekir. 
$\mathrm{Bu}$ araştırmada eşitlikçi toplumsal cinsiyet algısı ile cinsel eğitime yönelik olumlu tutumlar, eşitlikçi olmayan toplumsal cinsiyet algısı ile cinsel eğitime yönelik olumsuz tutumlar arasında ilişki olduğu belirlenmiştir. Modern koşullarda okul öncesi çocuklarda cinsiyet öz kimlik oluşumu sorunu giderek artmaktadır. Pugach ve Vertuhina (2020), aile eğitiminde etkili bir çalışma aracı olarak sunulan internet sitesinin, çocukların cinsiyete dayalı öz-kimliklerinin ebeveynlerini desteklemeyi amaçladığı araştırma sonucunda, bilgi ve iletişim teknolojisinin iletişim ve eğitim aracı olarak kullanma deneyimi sunduğu, yetişkinlerde okul öncesi çocuklarda cinsiyet öz-kimlik oluşum aşamalarını anlamada bilgi ve iletişim teknolojilerinin kullanılmasının önemini vurgulamışlardır. Yağan Güder ve Güler Yıldız (2016)'ın yaptıkları çalışma sonuçlarına göre, çocukların kadına ve erkeğe ilişkin kalıp yargısal görüş belirtmelerinde annelerinin ev hanımı olması, annelerin şiddete uğraması ve çocukların buna tanıklık etmesi, aile içi sorumlulukların geleneksel bir şekilde dağılması gibi faktörlerin etkili olduğu belirlenmiştir. Çalışmada çocukların toplumsal cinsiyet algılarının oluşmasında aile faktörünün önemli olduğu vurgulanmıştır. Araştırma sonuçları incelendiğinde, toplumsal cinsiyet algısını etkileyen birçok faktör olduğu, bu faktörlerin etkisinin ailelerin cinsel eğitime yönelik tutumlarıyla ilgili olduğu düşünülebilir.

$\mathrm{Bu}$ araştırmada cinsel eğitime yönelik tutumları olumlu olan ebeveynler çocuklarının cinsel eğitim almalarını istediklerini bildirmiştir. Tutum; değerlerin, inançların ve kültürün (kişisel, aile, arkadaşlar ve topluluk) tanımlanması için fırsatlar sunar. Ebeveynler cinsel eğitimde ilk basamak olarak tanımlanır. Ancak, ebeveynlerin ve çocukların cinsel davranış yönetiminde yeterliliğini hedef alan beceri geliştirme yaklaşımları mevcut programlarda yok denecek kadar azdır (Ganji ve diğerleri, 2017). Ebeveynlerin cinsel eğitimi gerekli gördüklerine ilişkin bulgular alanyazında yer almaktadır (Ceylan ve Çetin, 2015; Göçgeldi ve diğerleri, 2007). İşler (2017) okul öncesi dönem çocuğu olan ebeveynlerin cinsel gelişime ve cinsel eğitime yönelik bilgi düzeylerini ve tutumlarını incelemiş; ebeveynlerin cinsel eğitim verme konusunda kendilerini yeterli bulmadıklarını, cinsel eğitimi uzmanların ve/veya anne babaların vermesi gerektiğini, çocuklarıyla cinsellik konularında konuşmadıklarını, cinsel eğitimin çocukların gelişimlerini desteklediğini, çocuklarının cinsellik konularında doğru bilgiler edinmeleri ve cinsel istismardan korunabilmeleri için gerekli olduğu yönünde görüşe sahip olduklarını belirtmiştir. Başka bir çalışmada çocuk cinsel istismarını önleme programına katılan ebeveynler, Güvenli ve Sağlıklı Çocuklar Eğitimini tamamladıktan sonra, cinsel istismarın önlenmesi hakkında konuşmanın gelecekte daha kolay olacağını ifade etmiş ve eğitimin diğer ebeveynler için yararlı olacağını vurgulamıştır (Guastaferro, Zadzora, Reader, Shanley ve Noll, 2019).

Cinsel gelişim, çocuk gelişiminin çok önemli bir alanıdır ve yaşam boyu sürer. Bu nedenle erken dönemde aile içinde ve daha sonra da okul müfredat programlarında mutlaka ele alınmalıdır. Kız ve erkek çocuklar, okulöncesi dönemden başlayarak tüm öğrenim yaşamları boyunca cinsel eğitim konusunda bilinçlendirilmelidirler. Okul, özellikle ülkemiz gibi cinsel eğitimin tabu olarak görüldügü toplumlarda hem öğrenciler hem de anne babalar için bir eğitimci rolü üstlenecektir. Okullarda cinsel eğitime erken dönemde başlamak, ortaya çıkacak gelişimsel sorunları önleyeceği gibi diğer yandan da okulu erken terk eden çocuklara ulaşmış olmayı sağlayacaktır. Böylece geleceğin anne babaları hem bilgi hem tutum açısından desteklenerek, cinsel eğitim konusundaki olumsuz tutumlar da olumluya çevrilebilecektir.

Cinsel eğitimde kullanılan iletişim dili, ebeveynlerin cinsel eğitime yönelik tutumları ve bilgi düzeyleriyle ilişkilidir. Aslında bu ikisinin karşılıklı olarak birbirini geliştirebileceği gerçeği unutulmamalıdır. $O$ halde aileler, cinsel gelişim konusunda bilgilendirilir ve cinsel eğitim konusunda cesaretlendirilirken, iletişim dili konusu da ele alınmalıdır.

Geliştirilmiş olan bu ölçeğin farklı gruplarla kullanılması ve yanı sıra yeni ölçekler geliştirilmesi de önemlidir. Çünkü, ülke çapında cinsel eğitim hedeflerini belirleyebilmek için öncelikle mevcut durumun doğru değerlendirilebilmesi gerekmektedir. Ülke politikaları bu değerlendirmeler ışığında daha doğru şekilde oluşturulabilecektir. Bu nedenle araştırmada geliştirilen ölçeğin, cinsel eğitimle ilgili araştırma konularında araştırmacılara ışık tutabileceği düşünülmektedir. Aynı zamanda, ülkemizde ölçeğin ailelerin cinsel eğitim konusunda bilinçlenmesinde geliştirilecek eğitim programlarına katkı sağlayabileceği düşünülmüştür. Aynı zamanda, artan eğitim durumunun ebeveynlerin cinsel eğitime yönelik tutumlarını daha olumlu etkilediği sonucu, eğitimin çok önemli olduğu gerçeğini tekrar vurgulamaktadır. Bu nedenle, cinsel eğitime yönelik 
eğitimler eğitim düzeyi düşük gruplara ağırlık verilerek arttırılmalıdır. Araştırmada, eşitlikçi olmayan toplumsal cinsiyet algısı ile cinsel eğitime yönelik olumsuz tutumlar arasında ilişki olduğu belirlenmiştir. Bu bağlamda, ailelerin çocuklarının cinsiyet eşitliğine duyarlı bireyler olarak yetişmelerinde uygun rol model olmaları ve bilinçlendirilmesi için cinsel eğitimin önemi ortaya çıkmaktadır. Buna yönelik, ailelere yaparak yaşayarak davranış değişikliği oluşturmada etkili olan drama, rol oynama vb. yöntemler kullanılarak eğitimler düzenlenebilir. Cinsel eğitime yönelik tutumları olumlu olan ebeveynler çocuklarının cinsel eğitim almalarını istediklerini belirtmişlerdir. Ailelerin olumlu tutum geliştirmesi uzun soluklu bir süreç olduğu düşünülürse, eğitimlerin daha iyi planlanarak sürece yayılması gerekmektedir.

\section{Yazar(lar)ın Beyanı}

Araştırmacıların katkı oranı beyanı: Çalışmanın tüm süreçleri yazarlar tarafından ortak gerçekleştirilmiştir.

Çatışma beyanı: Araştırmada, yazarların kendi içinde ve diğer kişi/kurum/kuruşlarla herhangi bir çıkar çatışması söz konusu değildir.

Destek ve teşekkür: Bu araştırmanın gerçekleştirilmesi için herhangi kişi ya da kurumdan fon desteğgi sağlanmamıştır.

\section{Kaynaklar}

Altınova, H. H. ve Duyan, V. (2013). Toplumsal cinsiyet algısı ölçeğinin geçerlik ve güvenirlik çalışması. Toplum ve Sosyal Hizmet, 24(2), 9-22.

Artan, İ., Ceylan, Ş. ve Adıbatmaz Kurnaz, F. B. (2020). Ebeveynler için cinsel iletişim ölçeği: Güvenilirlik ve geçerlilik çalışması. Hacettepe Üniversitesi Să̆llk Bilimleri Fakültesi Dergisi, 7(2), 136- 158.

Artan, İ., Saranlı, A, G., Alkan Ersoy, Ö., Okutan, N. Ş., Özkızıklı S. ve Artan Özoran, B. (2015). Her yönüyle okul öncesi eğitim; cinsel gelişim ve eğitim. Ankara: Hedef Yayıncılık.

Bayhan, P. S. ve Artan, İ. (2005). Çocuk gelişimi ve eğitimi. İstanbul: Morpa Kültür Yayınları.

Brown, T. A. (2006). Confirmatory factor analyses for applied research (1. bs.). NY: Guilford Publications, Inc.

Bruess, C. E. ve Greenberg, J. S. (2004). Sexuality education (4. bs.). USA:Jones and Bartlett Publishers.

Byers, E. S., Sears, H. A. ve Weaver, A. D. (2008). Parents' reports of sexual communication with children in kindergarten to grade 8. Journal of Marriage and Family, 70(1), 86- 96.

Büyüköztürk, Ş., Çokluk, Ö. ve Köklü, N. (2010). Sosyal bilimler için istatistik (6. bs.). Ankara: Pegem Akademi.

Ceylan, Ş. ve Çetin, A. (2015). Okulöncesi eğitim kurumlarına devam eden çocukların cinsel eğitimine ilişkin ebeveyn görüşlerinin incelenmesi. Hacettepe Üniversitesi Sağlık Bilimleri Fakültesi Dergisi, 2(3), 41-59.

Comrey, A. L. ve Lee, H. B. (1992). A first course factor analyses. Hillsdale, New Jersey: Erlbaum.

Çalışır, D. (2011). Cinsel eğitim çocukluktan ergenliğge. İstanbul: Profil Yayınları.

Çokluk, Ö., Şekercioğlu, G. ve Büyüköztürk, Ş. (2010). Sosyal bilimler için çok değişkenli istatistik SPSS ve LISREL uygulamaları (1. bs.). Ankara: PegemAkademi.

Downie, J. ve Coates, R. (1999) The impact of gender on parent-child sexuality communication: Has anything changed? Sexual and Marital Therapy, 14(2), 109-121.

Eliküçük, A. ve Sönmez, S. (2011). 6 yaş çocuklarının cinsel gelişim ve eğitimiyle ilgili ebeveyn görüşlerinin incelenmesi. Sosyal Politika Çalışmaları Dergisi, 25(25), 45-62.

Erbil, N., Orak, E. ve Bektaş, A. E. (2010). Anneler cinsel eğitim konusunda ne biliyor, kızlarına ne kadar cinsel eğitim veriyor? Uluslararası İnsan Bilimleri Dergisi, 7(1), 366-383.

Erenoğlu, R., ve Bayraktar, E. (2017). Sexual attitudes of nursing students and the affecting factors. Journal of Human Sciences, 14(2), 1745-1756. 
Eroğlu, K. ve Gölbaşı, Z. (2005). Cinsel eğitimde ebeveynlerin yeri: Ne yapıyorlar, ne yaşıyorlar? Anadolu Hemşirelik ve Sağlık Bilimleri Dergisi, 8(2), 12-21.

Flanagan, P. (2011). Making sense of children's sexuality: Understanding sexual development and activity in education contexts. Waikato Journal of Education, 16(3), 69-79.

Ganji, J., Emamian, M. H., Maasoumi, R., Keramat, A. ve Khoei, E. M. (2017). The existing approaches to sexuality education targeting children: A review article. Iranian journal of public health, 46(7), 890-898.

Göçgeldi, E., Tüzün, H., Türker, T. ve Şimşek, I. (2007). Okul öncesi dönem çocuğu olan anne ve babaların çocuklara cinsel eğitim konusundaki yaklaşımlarının incelenmesi. Sürekli Tıp Eğitim Dergisi (STED), 16(9), 134-142.

Guastaferro, K., Zadzora, K. M., Reader, J. M., Shanley, J. ve Noll, J. G. (2019). A parent-focused child sexual abuse prevention program: Development, acceptability, and feasibility. Journal of child and family studies, 28(7), 1862-1877.

İşler, S. (2017). Okul öncesi dönem çocuğu olan ebeveynlerin cinsel gelişime ve cinsel eğitime yönelik bilgi düzeylerinin ve tutumlarının incelenmesi (Yayınlanmamış yüksek lisans tezi). Doğu Akdeniz Üniversitesi, Kuzey Kıbrıs.

İşler, S. ve Gürşimşek, A. I. (2018). 3-6 yaş çocuklarının cinsel eğitiminin gerekliliği ile ilgili ebeveyn görüşlerinin incelenmesi. Gazi Üniversitesi Gazi Eğitim Fakültesi Dergisi, 38(3), 845-867.

Janda, L. H. (1998). Psychological testing; theory and applications. Allyn\&Bacon, 160 Gould Street, Needham Heights, MA 02194.

Jankovi, S., Malatestini, G. ve Striehl, H. B. (2013). Parents' attitudes on sexual education - What and when? Collegium Antropoogicum, 37(1), 17-22.

Kline, P. (1994). An easy guide to factor analyses. New York: Routledge.

Kline, R. B. (2005). Principles and practice of structural equation modeling (2. bs.). NY: Guilford Publications, Inc.

Kristiana, S., Jamaris, M. ve Sumantri, M. S. (2006). Utilization of demonstration methods as sex education in early childhood. International Journal of Multidiciplinary and Current Research, 6, 811-814.

Kurtuncu, M., Utas Akhan, L. U., Tanır, I. M. ve Yıldız, H. (2015). The sexual development and education of preschool children: knowledge and opinions from doctors and nurses. Sexuality and disability, 33(2), 207221.

Liu, W. ve Edwards, C.P. (2003). Chinese parents' knowledge, attitudes, and practices about sexuality education for adolescents in the family. Faculty Publications, Department of Child, Youth, and Family Studies, 17, 1-17. 15 Haziran 2020 tarihinde https://digitalcommons.unl.edu/famconfacpub/17/ adresinden erişildi.

McNab, W. L. (1976). Sexual attitude development in children and the parents' role. Journal of School Health, $46(9), 537-542$.

Nagpal, A. N. ve Fernandes, C. (2015). Attitudes of parents towards sex education. The International Journal of Indian Psychology, 2(4), 38-43.

$\mathrm{Ni}, \mathrm{X}$. (2003). A study on the performance status and the strategies of the sex education preschool children (Yüksek lisans tezi). Northwest Normal University, Nanzhou.

Nyarko, K., Adentwi, K.I., Asumeng, M. ve Ahulu, L.D. (2014). Parental attitude towards sex education at the lower primary in Ghana. International Journal of Elementary Education, 3(2), 21-29.

Oktavianingsih, E. ve Ayriza, Y. (2018). Teachers' knowledge and belief for educating sexuality for kindergarten students. International Journal of Pedagogy and Teacher Education, 2(2), 307-318.

Opara, P. I., Eke, G. K. ve Akani, N. A. (2010). Mothers perception of sexuality education for children. Nigerian Journal Medicine, 19(2), 168-72. 
Pop, M. V. ve Rusu, A. S. (2015). The role of parents in shaping and improving the sexual health of childrenlines of developing parental sexuality education programmes. Procedia-Social and Behavioral Sciences, 209, 395-401.

Pugach, A. ve Vertuhina, V. (2020). ICT as a tool for forming gender self-identity in preschool children (No. 2797). Easy Chair Preprint.

Purba, N. (2012). Pendidikan Seks Untuk Anak Usia Dini Tunagrahita Ringan Kelas 3 SD (Yüksek lisans tezi). State University of Jakarta, Jakarta.

Sezgin, E. ve Akyüz, E. Y. (2018). Investigation of sexual training to children with parent perspective. İstanbul: The Book of Proceedings \& Abstracts.

Shin, H., Lee, J. M. ve Min, J. Y. (2019). Sexual knowledge, sexual attitudes, and perceptions and actualities of sex education among elementary school parents. Child Health Nursing Research, 25(3), 312-323.

Steiger, J. H. (2007). Understanding the limitations of global fit assessment in structural equation modeling. Personality and Individual Differences, 42(5), 893-898.

Tabachnick, B. G. ve Fidell, L. S. (2001). Using multivariate statistics (4. bs.). MA: Allyn \& Bacon, Inc.

Tavşancıl, E. (2005). Tutumların ölçülmesi ve SPSS ile veri analizi. Ankara: Nobel Yayınları.

Tuğrul, B. ve Artan, İ. (2001). Çocukların cinsel eğitimi ile ilgili anne görüşlerinin incelenmesi. Hacettepe Üniversitesi Ĕ̆itim Fakültesi Dergisi, 20, 141-149.

Tuğut, N. ve Gölbaşı, Z. (2019). Okul öncesi dönem çocuğu olan (3-6 yaş) ebeveynlerin cinsel eğitim tutumlarının belirlenmesi. Turkish Journal of Family Medicine and Primary Care, 13(3), 287-294.

Tuzcuoğlu, N. ve Tuzcuoğlu, S. (1996). Çocuğun cinsel eğitiminde ailelerin karşılaştıkları güçlükler. M.Ü. Atatürk Ĕ̆itim Fakültesi Eğitim Bilimleri Dergisi, 8, 251-262.

Tuzcuoğlu, N. ve Tuzcuoğlu, S. (2004). Çocuğun cinsel eğitimi. İstanbul: Morpa Kültür Yayınevi.

World Health Organization. (2006). The world health report 2006: Working together for health. Switzerland: World Health Organization.

Yağan Güder, S. ve Güler Yıldız, T. (2016). Okul öncesi dönemdeki çocukların toplumsal cinsiyet algılarında ailenin rolü. Hacettepe Üniversitesi Ĕ̆itim Fakültesi Dergisi, 31(2), 424-446.

Yılmaz, M. T. (2017). Cinsel gelişim. E. Deniz (Ed.), Erken çocukluk döneminde gelişim (s. 285-314) içinde. Ankara: Pegem Akademi Yayıncılık.

Yonghong, G. (2007). Education on preschool children's sex psychological behaviors and sex mental health, Chinese Journal of School Health, 3, 260-272.

Yuhong, W. (2004). Sex education, start from children born. Early Childhood Education, 22, 9-10.

Zhina, C. ve Dingchu, W. (2013). A review of sex education for preschool children in mainland China from 1992 to 2012. International Reiew of Social Sciences and Humanities, 5(2), 12-18. 


\section{EXTENDED ABSTRACT}

\section{Introduction}

With sexual education programs, children should acquire basic contents such as body awareness, rules including restrictions on touching / looking at others or genitals, awareness of emotions and expressions in accordance with current conditions, self-confidence (Oktavianingsih and Ayriza, 2018). In our country, it is seen that there is not yet an education on sexual education in early childhood in schools. Sex education in the family is very important for the development of children. As in many countries, sexuality issues are not easily discussed within the family in our country. Many adults state that it is very difficult to answer children's sexual questions and to inform their children about sexuality. However, there is also a common idea that children should not be too concerned about sexuality (Flanagan, 2011). The World Health Organization states that children learn about sexual information from sources such as the circle of friends and the media. Learning sexuality, which is an important part of life, from sources that provide incomplete or incorrect information, can negatively improve the child's perception of sexuality. It is possible to say that the attitudes of the family to give sexual education to their children affect children's perception of sexuality (Eliküçük and Sönmez, 2011; Eroğlu and Gölbaşı, 2005; Tuğut and Gölbaşı, 2019). When examining the literature in Turkey, it is observed that there could be used as a measuring tool to determine their attitudes towards sex education of the parents.

\section{Method}

In the development of the scale, a large literature review was made, and a preliminary information about the structure was obtained with a small application carried out with 100 people. 55 experimental attitudes were written for sexual education. After the items are written, the opinions of six experts are obtained, the items are clear, understandable, conformity to the measured feature, etc. It has been revised in terms of criteria. The revised test form and the Communication Language Scale used in Sex Education were applied to 199 people and Confirmatory Factor Analysis (CFA) was performed using the obtained data. As a result of CFA, the final form of the measurement tool, which is thought to exhibit a four-factor component structure, was created. The final form is 39 items and has four factors. CFAwas applied on the data obtained and it was concluded that the structure was confirmed due to the high index of goodness of fit. The final form was retested in a third group with the Gender Perception Scale, and the results were checked by confirmatory factor analysis.

\section{Results}

The attitude scale towards sexual education consists of 39 items. The scale includes 8 items in the first factor, 8 items in the second factor, 12 items in the third factor, and 11 items in the fourth factor. The lowest score that can be obtained from the scale is 39 , and the highest score is 156 . The scores obtained from the items of the 39-item scale with four factors are summed. The high total score indicates that the parents' attitudes towards sexual education are positive. Since all of the items in the avoidance factor contain negative judgment, it is useful to find those items at the end of the scale during application. The internal consistency coefficient of the scale consisting of 39 items was calculated as .90 . Based on the CFA results, it was decided that the results of the scale can produce valid findings. It was determined that there were moderate significant relationships among the sub-dimensions of the scale.

\section{Conclusion}

Genders of parents do not cause any difference in their attitudes towards sexual education. Education levels of parents cause a significant difference in their attitudes towards sexual education. In the study, it was determined that parents who graduated from higher education developed more positive attitudes towards sexual education. This suggests that the level of knowledge about sexual education can lead to more positive attitudes. It has been concluded that there is a positive relationship between parents' attitudes towards sexual education and the language of communication used in sexual education, and attitudes towards sexual education can change the language used by parents in sexual education. In this study, it has been determined that there is a relationship between the perception of egalitarian gender and positive attitudes towards sexual 
education, and the negative attitude towards non-egalitarian gender perception and sexual education. It is thought that the scale developed in the research can shed light on researchers about sexual education. At the same time, considering that the scale is an important step in raising awareness of families about sexual education in our country, experts can use this scale as a determinant when working with families and in education. 


\section{Ek 1: Cinsel Eğitime Yönelik Tutum Ölçeği}

Sevgili Anne ve baba,

Dört yaşındaki çocuğumuz bize nasıl doğduğunu sorabilir. Altı yaşına geldiğinde kadınların ve erkeklerin bedensel farklılıkları hakkında konuşmak isteyebilir. Ergenlik döneminde nasıl gebe kalındığını ya da kadınların âdet kanamalarını sorabilir. Çocuğunuzun bu gibi sorularını düşünerek aşağıdaki maddeleri okuyun ve sizin için uygun olan seçeneği işaretleyin.

Lütfen içtenlikle yanıtlayınız. Teşekkürler.

\begin{tabular}{|c|c|c|c|c|c|}
\hline & Madde & 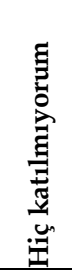 & 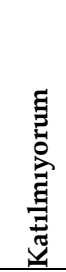 & 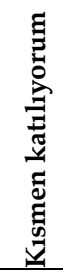 & 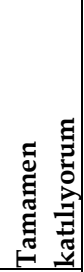 \\
\hline 1 & Okulda cinsel eğitimle ilgili ailelere yönelik toplantılar düzenlendiğinde katılmak isterim. & (1) & (2) & (3) & (4) \\
\hline 2 & Çocuğumun cinsel sorunlarıyla ilgili uzman desteği almak isterim. & (1) & (2) & (3) & (4) \\
\hline 3 & $\begin{array}{l}\text { Cinsel eğitimin insanların cinselliğine, başkalarının haklarına saygı göstermek için gerekli } \\
\text { olduğuna inanyorum. }\end{array}$ & (1) & (2) & (3) & (4) \\
\hline 4 & Çocuğa erken yaşta cinsel eğitim vermenin onu cinsel istismardan koruyacağını düşünürüm. & (1) & (2) & (3) & (4) \\
\hline 5 & $\begin{array}{l}\text { Çocuğuma cinsel eğitim verme sürecimde uzmanlardan (profesyoneller ya da rehber } \\
\text { öğretmenler) destek almayı isterim. }\end{array}$ & (1) & (2) & (3) & (4) \\
\hline 6 & $\begin{array}{l}\text { Cinsel eğitimin insanların görüşlerine ve olaylara bakış açlarına saygı göstermek için gerekli } \\
\text { olduğuna inanıyorum. }\end{array}$ & (1) & (2) & (3) & (4) \\
\hline 7 & Çocuğumla ilgili bir cinsel sorun fark ettiğimde uzmana başvururum. & (1) & (2) & (3) & (4) \\
\hline 8 & $\begin{array}{l}\text { Okulda çocuklara cinsel eğitim verilmeden önce anne babalara cinsel eğitimin içeriğiyle ilgili } \\
\text { bilgi verilmesi beni rahatlatır. }\end{array}$ & (1) & (2) & (3) & (4) \\
\hline 9 & Cinsel eğitimin ailede başlaması gerektiğini düşünürüm. & (1) & (2) & (3) & (4) \\
\hline 10 & Anne ve babaların çocuklarına cinsel eğitim vermeye istekli olmaları gerektiğini düşünürüm. & (1) & (2) & (3) & (4) \\
\hline 11 & Çocuğumun cinsellikle ilgili sorular sorması için fırsat yaratırım. & (1) & (2) & (3) & (4) \\
\hline 12 & Çocuğumun cinsel konularla ilgili neler bildiğini öğrenmek için fırsatlar yaratırım. & (1) & (2) & (3) & (4) \\
\hline 13 & Cinsel eğitimle ilgili bilgileri vermek öncelikle ebeveynlerin sorumluluğundadır. & (1) & (2) & (3) & (4) \\
\hline 14 & Ergenliğe kadar olan dönemde çocuğumun cinsel eğitiminde rol almak isterim. & (1) & (2) & (3) & (4) \\
\hline 15 & $\begin{array}{l}\text { Doğumdan itibaren verilen cinsel eğitimin çocukta olumlu davranışlar geliştirdiğini } \\
\text { düşünürüm. }\end{array}$ & (1) & (2) & (3) & (4) \\
\hline 16 & Çocuğumun cinsel konularla ilgili neler bildiğini öğrenmek için soru sormasını beklemem. & (1) & (2) & (3) & (4) \\
\hline 17 & Cinsel eğitimin çocuğun değer yargılarını olumlu yönde geliştirdiğini düşünüyorum. & (1) & (2) & (3) & (4) \\
\hline 18 & Çocuğumun cinsel eğitim almasının, cinsellikle ilgili yanlış bilgilerini düzleteceğini düşünürüm. & (1) & (2) & (3) & (4) \\
\hline 19 & $\begin{array}{l}\text { Cinsel eğitimin çocuğumun gelecekte karşı cinsle kuracağı ilişkileri olumlu yönde etkileyeceğini } \\
\text { düşünüyorum. }\end{array}$ & (1) & (2) & (3) & (4) \\
\hline 20 & Çocuğun yaşına uygun cinsel eğitim verilmesi gerektiğini düşünüyorum. & (1) & (2) & (3) & (4) \\
\hline 21 & Adet görmeden kısa bir zaman önce kız çocuklarının bilgilendirilmesi gerektiğini düşünürüm. & (1) & (2) & (3) & (4) \\
\hline 22 & $\begin{array}{l}\text { Cinsel eğitim kapsamında hem kız hem erkek çocuklara bedenini koruma konusunda bilgi } \\
\text { verilmesi gerektiğini düşünürüm. }\end{array}$ & (1) & (2) & (3) & (4) \\
\hline 23 & $\begin{array}{l}\text { Çocuğumun cinsel gelişimle ilgili sorduğu soruları, doğru olarak ve geçiştirmeden yanıtlamam } \\
\text { gerektiğini düşünürüm. }\end{array}$ & (1) & (2) & (3) & (4) \\
\hline 24 & $\begin{array}{l}\text { Cinsel eğitimin çocuğumun gelecekte kuracağı arkadaşlık ilişkileri olumlu yönde etkileyeceğini } \\
\text { düşünüyorum. }\end{array}$ & (1) & (2) & (3) & (4) \\
\hline 25 & $\begin{array}{l}\text { Çocuğumda fark ettiğim cinsel sorunlarla ilgili uzman desteği almanın önemli olduğunu } \\
\text { düşünüyorum. }\end{array}$ & (1) & (2) & (3) & (4) \\
\hline 26 & Çocuğumun cinsellikle ilgili merakının beklenen normal bir durum olduğunu düşünürüm. & (1) & (2) & (3) & (4) \\
\hline 27 & $\begin{array}{l}\text { Çocuğumun cinsellikle ilgili sorular sormasının onun gelişim sürecinin bir parçası olduğunu } \\
\text { düşünürüm. }\end{array}$ & (1) & (2) & (3) & (4) \\
\hline 28 & $\begin{array}{l}\text { Çocuğumun cinsel eğitimle ilgili birçok şeyi, ben anlatmadan önce arkadaşlarından } \\
\text { öğrenmesinin sakıncalı sonuçlar doğuracağın düşünürüm. }\end{array}$ & (1) & (2) & (3) & (4) \\
\hline 29 & Çocuğumun cinsellikle ilgili merak ettiği şeyleri sorgulamasından hoşlanmam. & (1) & (2) & (3) & (4) \\
\hline 30 & Çocuğumla doğum ve gebelik konularını konuşmaktan hoşlanmam. & (1) & (2) & (3) & (4) \\
\hline 31 & Çocuğumun ergenlik dönemine kadar cinsel eğitimle ilgili bilgi edinmesini istemem. & (1) & (2) & (3) & (4) \\
\hline 32 & Çocuğumun cinsellikle ilgili sorular sorması beni rahatsız eder. & (1) & (2) & (3) & (4) \\
\hline 33 & Çocuğun cinsel merakını artıracağını düşündüğüm için cinsel eğitimin verilmesini istemem. & (1) & (2) & (3) & (4) \\
\hline 34 & Ebeveynlerin çocuklarının cinsel eğitimlerine katılmasını uygun bulmam. & (1) & (2) & (3) & (4) \\
\hline
\end{tabular}


Şehnaz CEYLAN, İsmihan ARTAN \& Fatma Betül KURNAZ ADIBATMAZ

\begin{tabular}{|l|l|l|l|l|l|}
\hline 35 & Çocuğumun erken yaşlarda cinsel eğitim almasını istemem. & 1 & $(2)$ & $(3)$ & $(4)$ \\
\hline 36 & Çocuğumla beden farklılıklarını konuları konuşmaktan hoşlanmam. & 1 & $(2)$ & $(3$ & $(4)$ \\
\hline 37 & Çocuğumun cinsel gelişime yönelik soru sorması beni rahatsız eder. & 1 & $(2)$ & $(3$ & $(4)$ \\
\hline 38 & Sakıncalı bulduğum için erken yaşlarda çocuğuma cinsel eğitim vermem. & 1 & $(2)$ & $(3)$ & $(4)$ \\
\hline 39 & Çocuğuma cinsel eğitimin karşı cins ebeveyni tarafından verilmesini istemem. & & & & \\
\hline
\end{tabular}

